\title{
Historical Ecology of Scandinavian Infield Systems
}

\author{
Ove Eriksson ${ }^{1, *}$, Matilda Arnell ${ }^{1}$ and Karl-Johan Lindholm ${ }^{2}$ (1) \\ 1 Department of Ecology, Environment and Plant Sciences, Stockholm University, SE-10691 Stockholm, Sweden; \\ matilda.arnell@su.se \\ 2 Department of Archaeology and Ancient History, Uppsala University, SE-75126 Uppsala, Sweden; \\ karl-johan.lindholm@arkeologi.uu.se \\ * Correspondence: ove.eriksson@su.se
}

\section{check for}

updates

Citation: Eriksson, O.; Arnell, M.; Lindholm, K.-J. Historical Ecology of Scandinavian Infield Systems. Sustainability 2021, 13, 817. https:// doi.org/10.3390/su13020817

Received: 18 December 2020 Accepted: 12 January 2021 Published: 15 January 2021

Publisher's Note: MDPI stays neutral with regard to jurisdictional clai$\mathrm{ms}$ in published maps and institutional affiliations.

Copyright: $\odot 2021$ by the authors. Licensee MDPI, Basel, Switzerland. This article is an open access article distributed under the terms and conditions of the Creative Commons Attribution (CC BY) license (https:// creativecommons.org/licenses/by/ $4.0 /)$.

\begin{abstract}
Infield systems originated during the early Iron Age and existed until the 19th century, although passing many transitions and changes. The core features of infield systems were enclosed infields with hay-meadows and crop fields, and unenclosed outland mainly used for livestock grazing. We examine the transitions and changes of domesticated landscapes with infield systems using the framework of human niche construction, focusing on reciprocal causation affecting change in both culture and environment. A first major transition occurred during the early Middle Ages, as a combined effect of a growing elite society and an increased availability of iron promoted expansion of villages with partly communal infields. A second major transition occurred during the 18th and 19th centuries, due to a then recognized inefficiency of agricultural production, leading to land reforms. In outlands, there was a continuous expansion of management throughout the whole period. Even though external factors had significant impacts as well, human niche construction affected a range of cultural and environmental features regarding the management and structure of domesticated landscapes with infield systems. Thus, niche construction theory is a useful framework for understanding the historical ecology of infield systems.
\end{abstract}

Keywords: agrarian history; Iron Age; hay-meadows; land reforms; landscape history; niche construction

\section{Introduction}

Research in historical ecology is cross-disciplinary, as the core objectives are to understand how interactions between societies and environments develop through time, and how these interactions have formed cultures and landscapes, e.g., [1-4]. Thus, historical ecology integrates topics from the humanities (e.g., history, archaeology, anthropology) and the natural sciences (e.g., ecology, vegetation science). These different academic disciplines have their own concepts and theories, as well as their own ways of understanding causation, i.e., why something happens, e.g., [5,6]. Accordingly, there is a need for conceptual frameworks with the ability to address questions and problems relevant for both the humanities and natural sciences, and also promote communication among researchers from these different disciplines.

Niche construction theory [7] is one framework that has been suggested as suitable for this purpose [8,9] (see Section 2 below). The overarching aim of this paper is to examine this suggestion, applied to the historical ecology of Scandinavian domesticated landscapes based on infield systems. Infield systems refer to a particular way of managing land and structuring land use, established during the early Iron Age, i.e., from the first centuries BC onwards [10-12]. Land was divided into infields (Swedish: Inägor) and outland (Swedish: Utmark). Infields were enclosed areas located near settlements incorporating semi-natural hay-meadows (i.e., manipulated, but comprising a native pool of species) used for production of livestock fodder, and permanent crop fields. The outland was located outside enclosures and was used mainly for livestock grazing, but also for collection of other 
resources. The outland may have been open land, but was probably mostly forest, or at least land with some cover of trees. Despite many later changes in organization and management of land, for example concerning agricultural implements, crop rotation, land ownership, and land reforms, the key elements of infield systems were maintained until the modernization of agriculture and forestry initiated mainly during the 19th century. In present-day landscapes, there are plenty of legacies from historical infield systems, for example wood pastures [13] and semi-natural grasslands [14]. These remnant habitats are often species-rich, and are a concern for conservation biology. Forests today are mostly used for production of pulp and timber, and legacies of former land use are generally overlooked in forests as compared with the semi-natural grasslands, despite the fact that outland forests were an essential component of the historical infield systems [15].

Several previous studies have dealt with different aspects of the remains of old cultural landscapes in Scandinavia, for example the origin of infield systems, e.g., [16,17], the origin of meadow management [18], land-use changes during the last century [19], and historical perspectives on species-pools and species richness in semi-natural grasslands, e.g., $[14,20-26]$.

In our examination of the historical ecology of infield systems, we cover the whole c. 2000 years of these systems' existence, including remaining legacies of infield systems in today's landscapes. A brief introduction to niche construction theory is useful before we present the specific objectives and questions.

\section{Niche Construction as a Conceptual Framework for Historical Ecology}

Niche construction theory $[7,27]$ is based on the idea that there is a continuously ongoing interaction between a niche-constructing agent (typically a species) and its environment. Niche construction is defined broadly as a process by which a species alters its own ecological niche, or the niches of other species, and the feedback of these alterations to the niche-constructing species. There are two different aspects of niche construction, the alteration of the environment (the niche) by a species (which may affect many other species as well), and the response by the niche-constructing species to the altered environment [27]. The ecological niche refers to resources and requirements utilized by the niche-constructing species, or any other conditions affecting the species. Two key points in niche construction theory are that as species alter their environment, they not only respond to it, and that there is a reciprocal causation, generally meaning that the processes affecting change in the niche-constructing species and in the environment are mutually influencing each other [28]. Over time, along with changes in the niche-constructing species, there is an ecological inheritance (memory) of past environmental alterations.

Niche construction may apply to any species, but when focusing on humans, it has been termed cultural niche construction or human niche construction, e.g., [8,29,30]. In human niche construction, cultural changes are mediated by learning, memory, and knowledge transfer, i.e., components of cultural evolution, e.g., [31], or, in general terms, expressions of learned knowledge [27]. Since the dawn of the human species, people have been able to manipulate natural resources; agriculture was the big leap in such a manipulation, and the development of early agriculture and domestication of plants and animals has been considered as a prime example of human niche construction, e.g., [29,32,33]. In addition, human niche construction has, for example, been applied to a general understanding of the history of human societies, e.g., [34], and to impacts of the human society on other biota, e.g., [35].

Analogously to domesticated plants and animals, one may consider whole landscapes as domesticated, e.g., [36], thus incorporating also different ways of organizing and managing land, i.e., how land use is conducted and how it is spatially structured across landscapes. A starting-point for this paper is the notion that niche construction theory would be suitable for handling the processes underlying how landscapes are domesticated. A key question is thus whether there is a feed-back loop between the changing landscapes and how people conceive, utilize, and manage land. 
There has been some disagreement about whether human niche construction necessarily reflects human intentionality. Hodder $[37,38]$ criticized human niche construction theory for its presumed assumption of goal-directed behavior of humans to improve the resource base of societies. "If humans deliberately enhance their environments, it is not because they just decide to do that or because they have been forced to by unexplained increases in population or by climate change, but because they have become caught up in particular bio-socio-material entanglements that make specific intentions and adaptive responses possible" [37] p. 172. Indeed, one of the advocates for human niche construction clearly presumes goal directed intentions: "Humans utilize their capacity for goal-directed behavior to engineer environments in ways that enhance the productivity and predictability of economically important species" [33] p. 326. In a sense, the whole idea with niche construction theory is that a species (e.g., humans) modify its own niche by manipulating resources and environment. However, there is no reason why human niche construction necessarily reflects human intentions. Actions can be goal-directed and intentional, but they could as well be unintentional, with unexpected consequences.

\section{Objectives}

As will be described in more detail in Sections 5 and 6 below, infield systems in Scandinavia existed from the early Iron Age, more than 2000 years ago, until the 19th century, and during this time-period, several changes took place without altering the infield systems' core components, i.e., enclosed managed semi-natural meadows and crop fields, and outland grazing by livestock. As a first reflection, it may seem obvious that this farming system was a way to: "( . . ) engineer environments in ways that enhance the productivity and predictability of economically important species" [33] p. 326. However, an essential feature of niche construction is reciprocal causation, that the processes changing the culture and the environment are mutually influencing each other. This would, for example, be manifested as a response of culture to the altered environment, in turn leading to new alterations in the environment, in turn leading to responses in culture, and so on. Our main objective is to examine whether this was the case. In order to do this, we first need to identify the most important changes in infield systems, from their origin to their end.

Thus, we ask two main questions: (1) Which were the key phases of transitions and change of domesticated landscapes with infield systems? (2) To what extent were these transitions and changes the result of niche construction, involving reciprocal causation between cultural features (e.g., management and how landscapes were perceived and organized), and features of the environment and landscape?

\section{Some Remarks on Approach and Terminology}

\subsection{A Retrospective Approach}

One methodological problem in historical ecology is how to examine land use far back in time, before we have access to written sources and maps. This study extends back to the early Iron Age, more than 2000 years ago. There are few written sources from Scandinavia before the 13th and 14th centuries AD (except from rune stones, raised from the 4th century onwards, with a particularly intensive phase in the 11th century). More extensive information regarding land use is not available before the 17th century, when cadastral maps (with associated information) were produced. Before that time, and certainly for the first millennium AD, interpretations are based mainly on material evidence such as remains of settlements, field systems, stone walls, etc. Pollen analyses contribute important information regarding general aspects of vegetation such as landscape openness and diversity, e.g., [39,40], and macrofossils contribute information on crops, e.g., [41], but information about the way people shaped and managed domesticated landscapes remains quite vague, e.g., [42]. Furthermore, the mind-set of people, such as conceptions on property and rights to use land, and how people understood the ecological mechanisms behind different kinds of management, for example manuring of crop fields, are mostly 
beyond reach for us. Thus, when examining how land use affected the landscape and vegetation before we have direct evidence, and the rationale for people's decisions, a few assumptions are needed. Firstly, it was assumed that historical effects of land use such as livestock grazing and production of fodder (hay, and leaf-hay) were similar to the effects we have knowledge about from recent times. A similar assumption was used for conceptions of ownership and land rights, as they have been interpreted based on the earliest written sources, e.g., [43]. Secondly, it was assumed that people behaved rationally, i.e., the way people used land (fields, meadows, pastures, etc.) was rational from the viewpoint of promoting productivity and securing subsistence, as far as that could be achieved within the frames of the material conditions (vegetation, crops and livestock, buildings, tools, etc.) available at that time. Taken together, these assumptions reflect a kind of retrospective approach to historical ecology.

\subsection{Terminology}

Most studies referred to in this paper have been conducted in Sweden, and some are from other countries, mainly Denmark and Norway. As these nation states did not exist at the time when infield systems were formed, the region is referred to as Scandinavia, as in the title of the paper. However, the history of infield systems after the formation of the Scandinavian nation states focuses on Sweden. The time-frames mentioned in the text refer to those used in Sweden: The Bronze Age (1800-500 BC), the Iron Age (500 BC-AD 1050), incorporating the early Iron Age (500 BC-AD 400), the Migration Period (AD 400-550), the Vendel Period (AD 550-750), and the Viking Age (AD 750-1050) [44]. The Middle Age is considered to begin around AD 1050 and continue until the beginning of the 16th century (In Sweden, AD 1520 is commonly used). For specification of times after the Middle Ages, we used the century (e.g., 19th century).

In the literature, there are different terms used for the farming people and their settlements through the historical period examined here, e.g., [10,45]. Throughout this paper, we use the term farmer, and we use the term farm to denote the basic agricultural unit, i.e., the settlement (we imagine) typically hosting a family, or a larger group of related people, and the land utilized by these people. Farms could be located in isolation, or they may have occurred in groups, e.g., [46]. The term used for such clusters of farms is village (Swedish: By), irrespective of their size.

\section{Infield Systems: Origin and Basic Features}

An infield system is a farming system where the essential features relate to the management of land and the spatial structuring of different land use $[16,18,47,48]$. Figure 1 shows the major components of infield systems, and the background of these components are summarized in Table 1. The area closest to settlements was enclosed by fencing (wooden fences or stone walls) in order to avoid uncontrolled grazing from livestock and wild herbivores. Within this area, land was used for the production of livestock fodder on semi-natural hay-meadows, and for permanent crop fields. There were many types of hay-meadows: Wooded meadows, producing both leaf-hay (twigs and leaves) and grass-hay (including also forbs), open dry meadows, and wetland meadows. The latter were dependent on settlement locations close to water bodies. The crop fields were fertilized with livestock manure. An old saying, "the meadow is the mother of the field", e.g., [49], reflects the tight connection between the two major land uses within the infields. Livestock mediated a nutrient transfer from fodder, not accessible as food for humans, via manure, to the crops. 


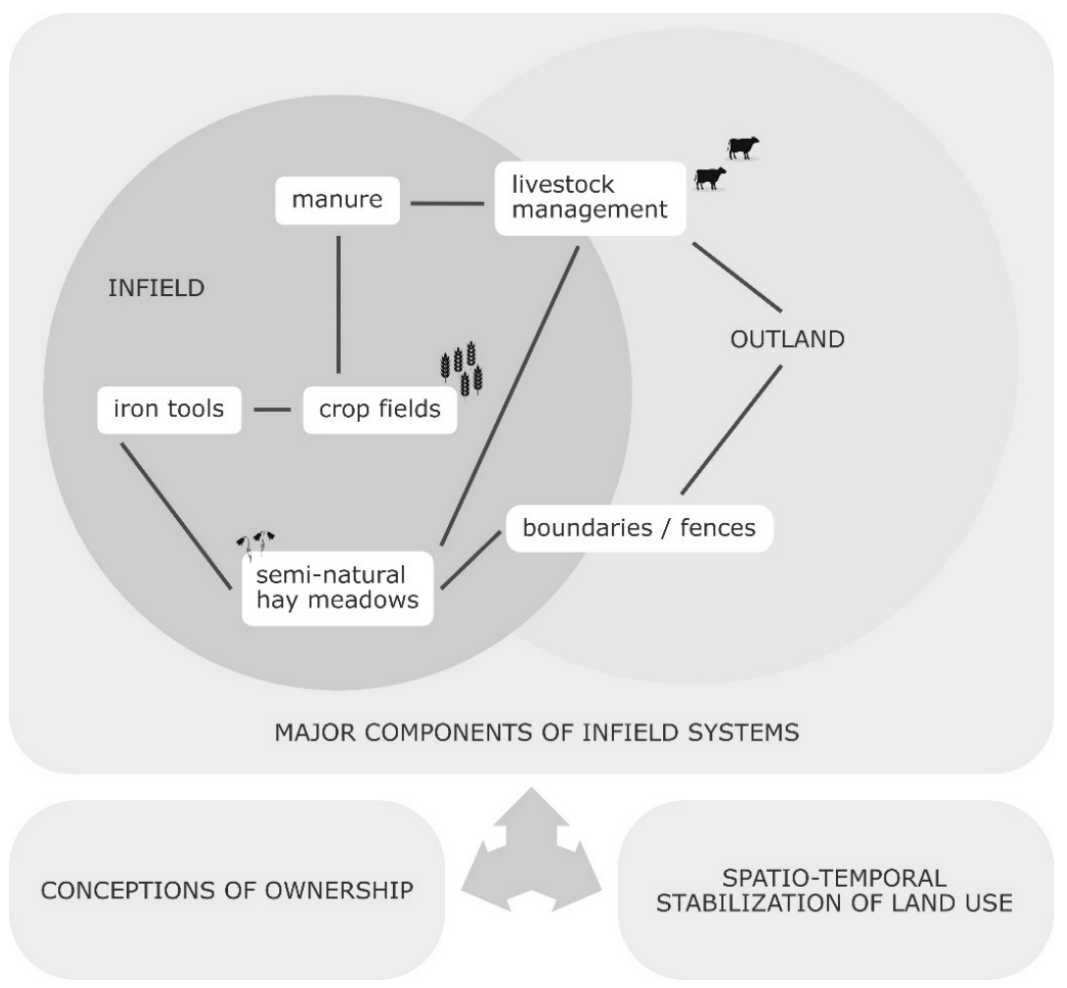

Figure 1. Schematic representation of the main components of Scandinavian infield systems.

Table 1. The main components of infield systems (see Figure 1) and their historical background.

\begin{tabular}{|c|c|}
\hline $\begin{array}{c}\text { Components of Infield } \\
\text { Systems }\end{array}$ & Historical Background \\
\hline Iron tools & $\begin{array}{l}\text { Iron production started during the late Bronze Age, but iron became generally available in } \\
\text { Scandinavia during the first centuries BC [50], and allowed for the development of tools and } \\
\text { efficient agricultural management, particularly the introduction of scythes necessary for efficient } \\
\text { use of hay-meadows [16]. }\end{array}$ \\
\hline $\begin{array}{l}\text { Boundaries and fencing } \\
\text { systems }\end{array}$ & $\begin{array}{l}\text { Various fencing systems, ditches, and wooden fences, were used long before infield systems } \\
\text { appeared [18]. Depending on availability of material, fences could be wooden or made of stone. } \\
\text { The importance of boundaries manifested in the landscape developed before infield systems [51]. }\end{array}$ \\
\hline Semi-natural hay-meadows & $\begin{array}{l}\text { Collection of additional fodder for livestock has occurred since the Neolithic, but land specifically } \\
\text { constructed and managed for this purpose developed during the centuries around } \\
\qquad 1 \mathrm{BC} / \mathrm{AD} 1 \text { [18]. }\end{array}$ \\
\hline Livestock management & $\begin{array}{l}\text { Livestock, i.e., goats, sheep, and cattle, were already part of the farming package during the } \\
\text { Scandinavian Neolithic [52], and it is likely that livestock were sometimes held in enclosures } \\
\text { although they otherwise mostly were herded on non-enclosed land. Pastoralism, i.e., farming } \\
\text { systems based on free-ranging livestock in extensive, probably communal, pastures was common } \\
\text { during the Bronze Age [53,54]. Stalling (keeping livestock indoors) occurred long before the } \\
\text { infield systems appeared, and was probably related to factors such as preventing cattle-raiding, } \\
\text { or increasing efficiency of milk production }[55,56] .\end{array}$ \\
\hline Manure & $\begin{array}{l}\text { Manuring of fields occurred already during the Neolithic [57], but became a necessity along with } \\
\text { the development of permanent fields. }\end{array}$ \\
\hline Crop fields & $\begin{array}{l}\text { The crop fields during the Scandinavian Neolithic were temporary [58]. Permanent field systems } \\
\text { managed by wooden ards were introduced during the first millennium BC, but probably before } \\
\text { manure was available in sufficient amounts, e.g., [59]. }\end{array}$ \\
\hline
\end{tabular}


Table 1. Cont.

\begin{tabular}{cc}
$\begin{array}{c}\text { Components of Infield } \\
\text { Systems }\end{array}$ & Historical Background \\
Outland & $\begin{array}{c}\text { Livestock probably grazed freely in the area surrounding settlements already during the } \\
\text { Neolithic, e.g., [60]. However, the recognition of outland as a defined part of land use presumes } \\
\text { that infields have been established. }\end{array}$ \\
\hline $\begin{array}{c}\text { Indirect evidence from various sources suggests that a conception of land as belonging to } \\
\text { individuals or families developed during early Iron Age, i.e., along with the infield } \\
\text { systems [43,61]. During the first centuries AD, there is also a trend of increasing inequality } \\
\text { among farms, reflecting developing societal power hierarchies, e.g., [62]. }\end{array}$ \\
$\begin{array}{r}\text { Spatio-temporal stabilization the establishment of infield systems, settlement patterns were more 'floating', i.e., farm } \\
\text { locations were changed each generation, e.g., [63]. Based on the remains of buildings, grave fields, } \\
\text { and place names, many farms in present-day Scandinavia have remained located at the same } \\
\text { place since the middle first millennium AD, or even longer, e.g., [16,64]. }\end{array}$ \\
\hline
\end{tabular}

The introduction of infield systems greatly increased the basis for people's subsistence [48]. The dominating crop during the Iron Age was hulled barley, but from late Iron Age and the Middle Age, other crops such as oats, wheat, and rye became more common, and could be regionally dominating [16]. Enclosed cattle paths led from the settlement to the outlands (sometimes referred to as outlying land or outfields), where livestock grazing took place during the vegetation period. The outland could be open tree-less vegetation, but it is likely that it most often was forest, perhaps semi-open due to the impacts of the grazing livestock. Figure 2 shows an example of an infield system from the first century $\mathrm{AD}$ in southeastern Sweden. In the following, we use this description of infield systems as a basic model, acknowledging that there was regional variation in Scandinavia in how infields were structured during the Iron Age [65].
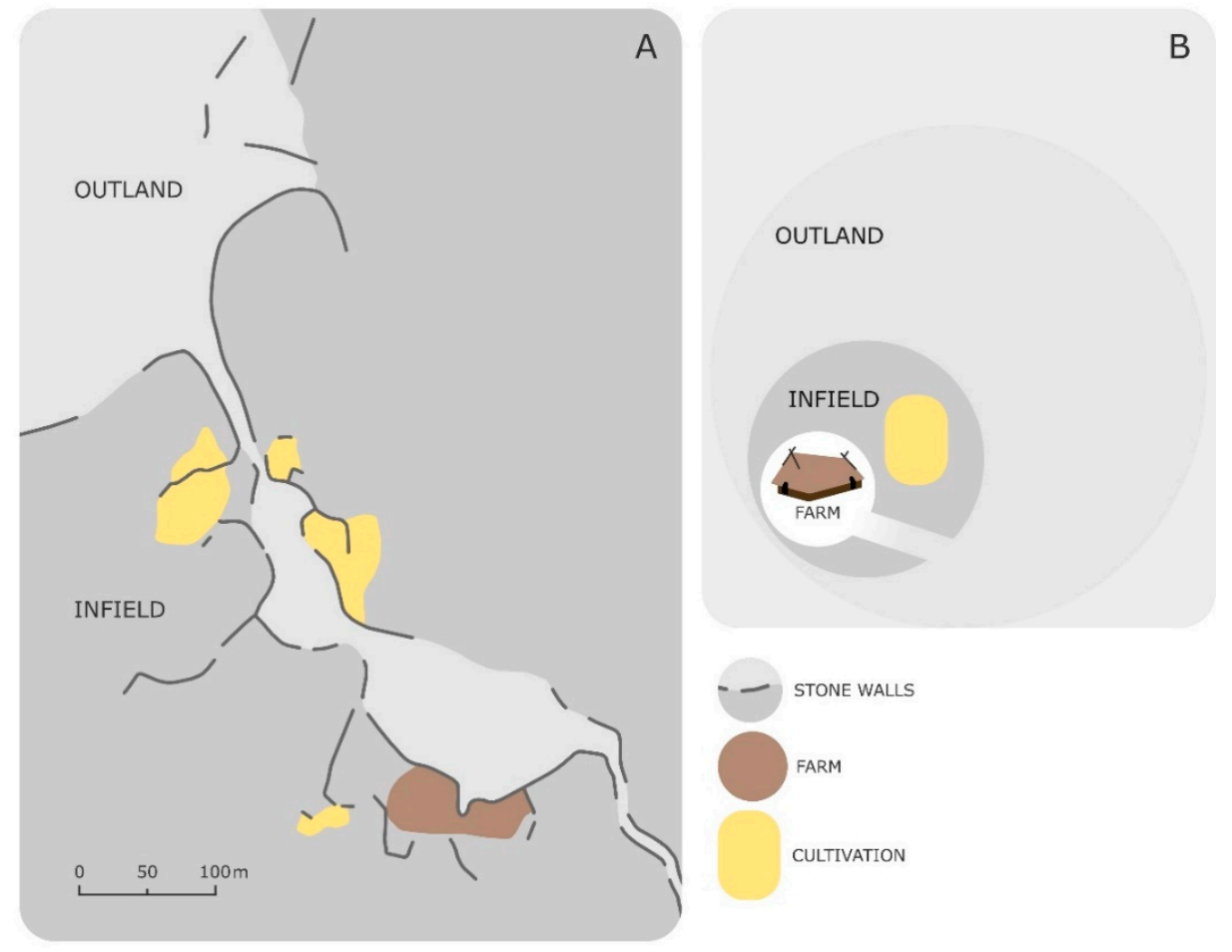

Figure 2. An infield system from the early Iron Age in southeastern Sweden. (A) A reconstruction based on remains of stone walls and interpretations of land use. (B) A generalized illustration of the basic structure of infield systems in the early Iron Age. (Re-drawn from Ref. [47]). 
In older literature infield systems were often understood as resulting from a need for keeping livestock indoors (stalling) due to a deteriorating climate during the first millennium BC. As a consequence of livestock stalling, it became necessary to produce winter fodder on meadows close to settlements, and these meadows needed to be protected from livestock grazing during summertime. Thus, infields developed. On close inspection, this explanation does not hold $[16,18,55]$. For example, stalling of livestock occurred long before the introduction of infield systems, and probably for other reasons than protection from an adverse climate. These reasons could be, for example, protection from cattle robbery, and enhancing production of milk and manure. The use of permanent fields also seems to precede the establishment of infield systems, and the earliest permanent field systems were not intensively manured $[59,66]$.

We should recognize that answering the question of origin is complex, and it is reasonable that there was a whole suite of processes, for example regarding livestock management, crops, and tools ultimately leading to establishment of this farming system, e.g., $[11,16,17,55]$. In this framework, it is also possible that the establishment of infields was associated with an emerging new mind-set in which it became important to manifest boundaries visualized in the landscape [51] and land became seen as a property, most likely of a family, e.g., [43]. Based on a synthesis of various evidence [18], it was concluded that a key to the origin of infield systems was the introduction of generally available iron tools necessary for efficient hay-meadow management. This timing also coincides fairly well with material evidence of stone wall systems such as those shown in Figure $2[47,67]$. The origin of infield systems was thus connected to a technological innovation, iron production, and can be placed in time in the early Iron Age.

\section{Major Transitions and Changes in Infield Systems}

The first question we ask in this paper is: Which were the key phases of transitions and change of domesticated landscapes with infield systems? We will first focus on this question for infields and outland, respectively, and thereafter consider the resilience of infield systems, and the processes that led to the end of infield systems.

\subsection{Key Transitions and Change in Infields}

Enclosed crop fields and hay-meadows, surrounded by outland used for livestock grazing, were largely maintained until the 19th century, and in some marginal regions even into the 20th century. Figure 3 gives an example of a cadastral map illustrating infields and outland during the 18th century. This does not mean that agriculture was static during this long period of time. Many features of agriculture changed, for example regarding agricultural implements and other technologies. In addition, the society changed considerably, and along with this also the general conditions under which farming was conducted. But the longue durée (cf. [68]) of infield systems implied that the basis for people's subsistence was largely the same: Livestock had a key role in the transfer of nutrients from hay, via manure, to crops. Crops, dairy products, and meat from livestock fed the human population, and the basic means to maintain this subsistence was a use of landscapes, structured as infields and outland. 


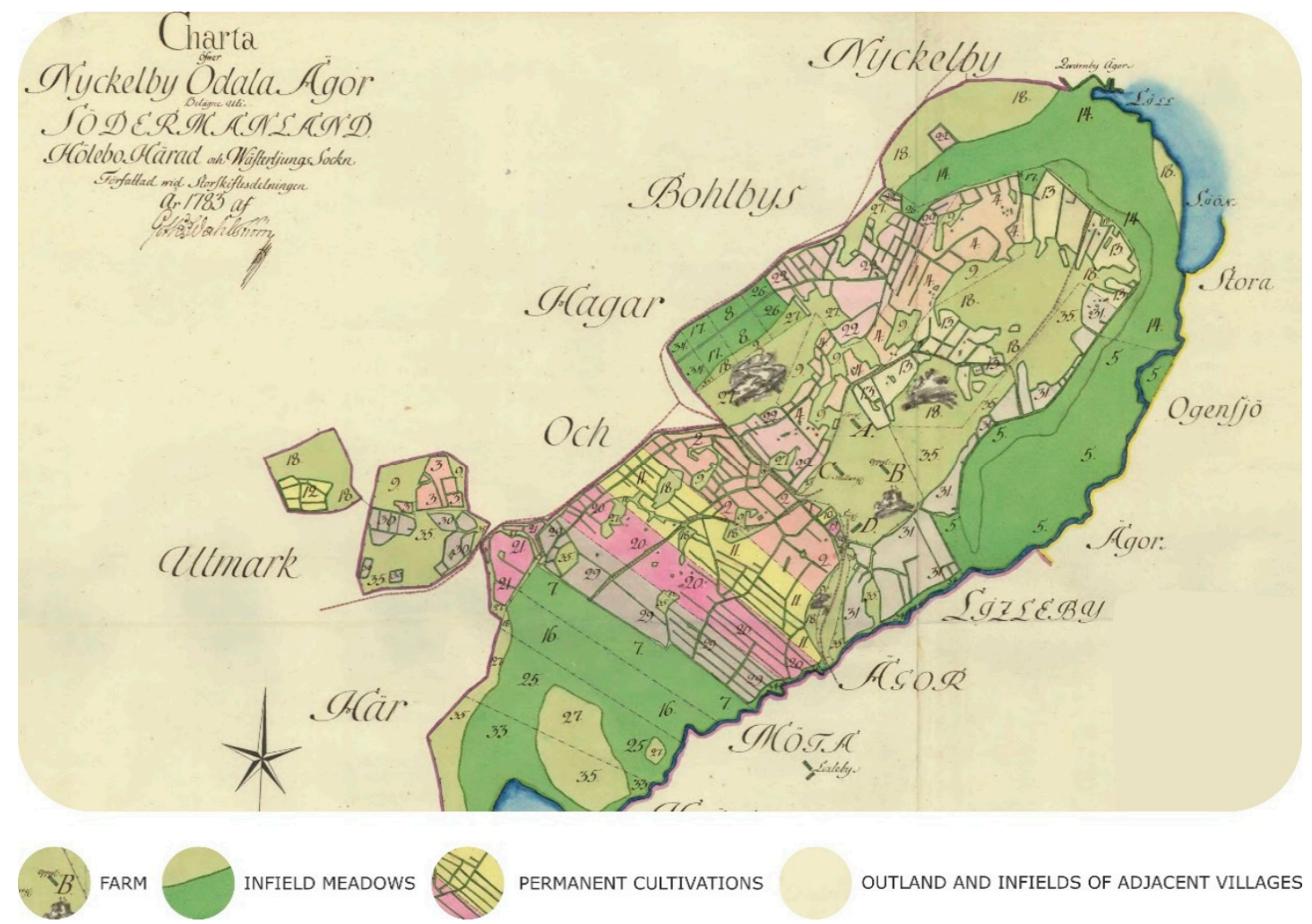

Figure 3. A cadastral map from the 18th century. Note that the cultivated fields are divided into strips of land belonging to individual farms in the village.

As with the question of the origin of infield systems, we should recognize that the changes during the following almost 2000 years were complex, and it may seem as too simplified to identify certain key transitions describing this change. However, when viewing this change at a broad resolution, it is reasonable to identify two major transitions altering management of infields and their spatial organization, before the ultimate end of infield systems (which is treated in Section 6.4).

The first of these key transitions was associated the introduction of crop rotation systems, and the implications this had for organization and structure of land use. At the initial phase of infield systems, the model used is a single farm with its own infields, meadows, and crop fields, surrounded by fences separating them from the outland (Figure 2B). Although implements made of iron (sickles, scythes) occurred, it seems likely that availability of iron was still quite limited. The fields were managed by wooden ards, and sown yearly by crops. After a crisis, probably related to a drastic climate change during the 6th and 7th centuries (see Section 6.3 below), many settlements were abandoned or relocated. Agriculture again expanded during the Viking Age and early Middle Age, but the conditions during this expansion was different than during the early Iron Age. This expansion was associated with a complex of changes, both regarding the agricultural technology and regarding the society as a whole [45]. The agricultural population increased, and settlements became more clustered. Villages became common, e.g., [46], and this implied that the organization of infields changed. These changes occurred in a context of a growing elite society, probably established in the aftermath of the 6th and 7th century crisis and consolidated during the Viking Age [44]. The elite society ultimately linked to a form of feudalism which developed along with the introduction of Christianity and the formation of the Scandinavian nation states between the 11th and 13th centuries [45]. Farmers had to pay tax to the King and the Church, or rent to a landlord. The villages became embedded in a feudal-like social network, which also became encoded by laws.

During the same period, an innovation in iron production technology, the introduction of the blast furnace, drastically increased the amount of available iron [69]. The consump- 
tion of iron in agriculture increased considerably [70], something that spurred innovation of agricultural technology, such as longer blades of scythes, iron-shod spades, and ploughs and ards with iron shares [45]. The latter implements made it possible to break the soil efficiently (not only scratch it, as with the wooden ard). This innovation was essential, as it allowed crop fields to be laid fallow for longer periods. Altogether, these changes in the conditions (societal and material) allowed for an efficient use of crop rotation systems, i.e., that a part (half, or a third) of the crop field area was used as fallow, grazed by livestock. Thus, in contrast to the initial infields during the early Iron Age, livestock would now continuously graze within the infields. In turn, this demanded new fencing practices, and as there were village communities with many farms, these had to be collectively organized, i.e., with fallows used as commons within the infield area. The overall implication of these changes, the expansion of agriculture in general, the altered way of locating settlements in villages, and the enforced collective fencing of the components of infields, was that the total areas of interconnected infields, i.e., hay-meadows, crop fields, and fallows, increased. The shape and structure of the domesticated landscape had been transformed.

This domesticated agricultural landscape was, with only minor changes, basically unaltered until the 18th and early 19th century [48], when a second major key transformation of infield systems occurred, an 'agricultural revolution' culminating in the launching of land reforms [71]. This agricultural revolution was driven by increasing demands for food, and spurred innovations and an increasing exploitation of land used for agriculture, including land that until then had been outland. The rationale behind the land reforms was to counteract what was recognized as inefficiency in agricultural management. First introduced in southern Sweden, the reforms ultimately concerned most of the country, except a few regions in central and northern Sweden. The essential idea was to re-allocate the infields so that each individual farmer managed interconnected land instead of strips of fields (Figure 3). As a consequence, villages were broken up into individual farms, located some distance from each other, resulting in a settlement structure that is still visible in the countryside of Sweden. When the land reforms were introduced, about a third of Sweden's farmers were free-holders, i.e., they owned their land [71]. The reforms were not always accepted voluntarily by these farmers, as they saw no immediate advantage of the reorganization of land, e.g., [72]. An important feature of the land reforms was that the outland, hitherto managed as commons, also started to become enclosed and allocated to individual farms [71,73]. A second implication was that an increasing fraction of the agricultural population became landless crofters, establishing small crofts in what was formerly outland [71].

Thus, for a second time since the Iron Age, the shape and structure of the domesticated agricultural landscape was transformed. This was, however, only a forerunner to the ultimate termination of infield systems.

\subsection{Key Transitions and Change in Outlands}

The outland was an integrated part of infield systems. A conception of infields presumed a contrast to the land located outside the enclosures, the outland, defined as beyond the infields. In the Swedish medieval landscape laws, there are various regulations for the use of outlands, illustrating their importance, e.g., [74]. However, since the outland was not described as detailed as the infields in cadastral maps, and the remains of previous management have been overlaid by modern forestry, thus usually being only vaguely visible in the current landscapes, we have much less knowledge about how outlands were used, as compared to infield hay-meadows and crop fields.

Outlands were used for various purposes, not only for livestock grazing. Production of iron and the necessary charcoal, e.g., [75] was conducted in the outland, and the same holds for production of tar, e.g., [76]. Materials used for buildings and fences were also gathered from the outland. In addition, ship building during the Viking Age demanded massive quantities of wood, obtained from the outland [44]. 
The focus here is, however, on the direct role of outland for agricultural production, and in what sense this was transformed during the history of infield systems. Except from the obvious change resulting from the land reforms described above, when outland commons were allocated to individual farms, it is difficult to identify specific transformations concerning the outland. It was rather a continuously ongoing expansion of outland use, which was manifested in different ways.

Livestock grazing was a dominating activity. Burning forest areas was used deliberately to improve grazing for cattle, sheep, and goats [77-79]. Studies based on analyses of fire scars and tree ring dating suggest that fire frequency increased from the Middle Age onwards, until the 19th century, most likely due to intentional burning [79,80]. In one study area in Southern Sweden, the fire interval was as small as c. 20 years [81]. In the most densely populated agricultural areas, the outland was heavily exploited by grazing livestock, e.g., [82]. One author remarked [83] (p. 395): “( . . ) in the 19th century, southern Sweden was to a great extent a large cow pasture".

In large tracts of Scandinavia, however, outland forests dominated the landscapes, especially in the central and northern parts, e.g., [74]. These forested areas started to become colonized by farmers around the time when the infield system was established in the early Iron Age, a colonization probably driven by a quest for iron production sites $[75,84,85]$, and hunting for crafts and trade $[86,87]$. Agriculture was thus established outside the main previously occupied agricultural regions, in an environment that initially can be described as a kind of macroscale outland in relation to agricultural regions. As people brought with them their knowledge of agriculture, they established infield systems comprising fields and meadows, surrounded by outland used for livestock grazing $[18,74,88]$.

Fodder for livestock was not only obtained from infield meadows, but also from wetlands located in the outland, e.g., [89]. From the last centuries, it is known that these outland wet meadows were often subjected to manipulation of the water regime in order to promote fodder production [90]. It is unclear when such manipulations initially were invented. Fodder was also obtained from harvesting twigs and leaves from deciduous trees and shrubs. The harvesting of such leaf hay was massive in Sweden until the 19th century [91]. All kinds of deciduous trees and shrubs were used. If available, tree species such as ash (Fraxinus excelsior), elm (Ulmus glabra), lime (Tilia cordata), and maple (Acer platanoides) were preferred. If these species were not available, for example in the central and northern parts of Sweden, other species such as birch (Betula spp.), goat willow (Salix caprea), aspen (Populus tremula), and rowan (Sorbus aucuparia) were used. It is likely that this type of hay was dominating initially during the colonization of outland forests [18].

Another manifestation of an increasing use of outlands was slash-and-burn cultivation, i.e., temporary fields established after the burning of forests. This management is often associated with a colonization from late 16th century onwards by people from Finland [48,92]. However, slash-and-burn cultivation occurred in southern Sweden much earlier, during the Middle Age, probably as a complement to the infield crop production [93]. There may have been a mutual relationship between slash-and-burn cultivation and other outland activities such as charcoal production (for production of iron), and, after a few years of cultivation, livestock grazing [94].

In central and northern Sweden, the landscape is generally less productive than in the south, implying that the area available for infields is more restricted. In order to expand the area useful for livestock grazing beyond the vicinity of a main farm, secondary farms (shielings) were established. It is controversial when the use of secondary farms originated, either already during the Iron Age, e.g., [74,95], or not until the late Middle Age [96]. There is, however, no doubt that the use of secondary farms increased until the late 19th century. The use of secondary farms implied transhumance. People (mostly females) moved to the secondary farm during summertime, herding the livestock and engaging in dairy production, for example cheese [96].

Thus, although it is difficult to identify specific transitions in outland use, there was a clear trend of expansion into outlands, and increasing exploitation of outlands (Figure 4). 
This exploitation also implied that new farms, with their own infields, were established beyond the borders of formerly occupied agricultural land. As mentioned above, establishing new farms in former outland was part of the agricultural revolution during the 18th and early 19th centuries. The expansion into the outland included innovations, such as systems of transhumance based on secondary farms, manipulation of outland wet meadows to promote fodder production, and a possible synergism between various activities, such as charcoal production, cultivation of crops, and improved conditions for livestock grazing.

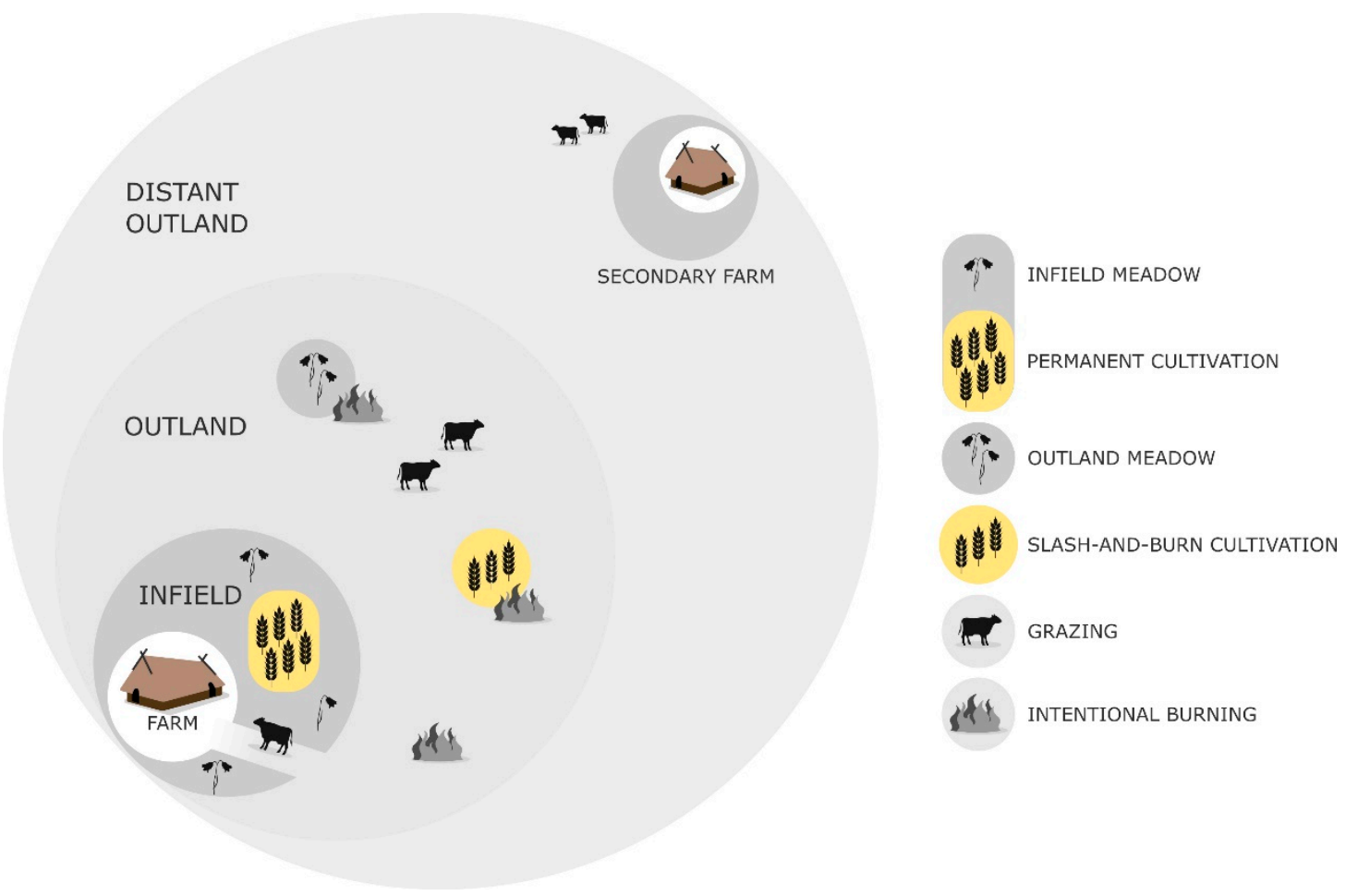

Figure 4. Schematic representation of the expanding outland management (viewed in one direction from the infields). (Inspired by Ref. [97]).

The outlands were generally regarded as commons, although they were subject to rules which from the Middle Age were defined by laws; these commons promoted and regulated cooperation among farmers, and they are likely to have been instrumental for joining people together in local communities, e.g., [73]. Even after the land reforms, which divided commons into privately owned land, some aspects of these commons remained, and still remain until today. One example is the Swedish legislation (similar in Norway and Finland) which gives right to public access to forests, and also allows for free collection of berries and mushrooms.

\subsection{Crisis and Resilience of Infields}

Despite the changes described in the two previous sections, one may remark that a farming system that existed for about 2000 years should have been very resilient. On closer inspection, this is indeed true. During this long period of time, there were several crises, among which two stand out as exceptional. It is instructive to briefly examine how these two crises played out within the frame of infield systems, and what features of the systems promoted resilience.

The first crisis occurred in the 6th century and was most likely caused by several gigantic volcanic eruptions (it is unclear where on Earth these were located) commencing in AD 536, resulting in a drastic reduction of sunlight and declining temperature, and initiating a period which has been termed the Late Antique Little Ice Age [98]. Possibly, the crisis was exacerbated by a plague (the Justinian plague). There is no direct evidence, material or 
written, describing how this crisis affected people in Scandinavia. However, in the time period between $\mathrm{AD} 300$ and $\mathrm{AD}$ 650, there was a reorganization of settlement patterns in large parts of Scandinavia, and it is likely that the climate crisis was an important factor behind the late phase of this reorganization. Many settlements were abandoned, and new settlements were established [64,99-101], often on slightly higher and drier ground [102]. It has been suggested that the memories of this crisis led to the legend of the Fimbulwinter, known from the Old Norse literature as a cold period without much sunlight during several consecutive summers [102]. It is likely that the direct impact on plant growth, and declining temperatures, severely hampered crop production. It has been suggested [103] that the crisis spurred a renegotiation of property rights for land that had been abandoned, promoting an increasingly unequal society. To use a modern term, land grabbing laid a foundation for new elites, forming the strongly stratified society which developed during the Vendel Period and the Viking Age [44]. In addition, the formation of villages increased during the Viking Age [46]. These changes were thus forerunners of the feudal-like society during the early Middle Age [45].

While the settlement structure changed, there are few indications of change in the basic land use [99]. The reliance of livestock may have increased [103], which is reasonable if the crops failed, and such a change would be manageable within the frame of infield systems. When land was abandoned, this would have increased the possibility to keep livestock for those farmers that survived the crisis. Even if crops failed, there should have been leaf-hay available for the livestock, provided that sufficient land areas (forests) were available for harvesting leaf-hay. A recent study from Finland [104] suggests that a general reliance of a multitude of food resources implied that people could withstand and survive the Fimbulwinter crisis.

A second crisis occurred during the 14th and 15th century, initiated by a plague (the 'Black Death'), but exacerbated by climate change, the Little Ice Age [105]. It has been termed the Late Medieval Agrarian Crisis, and it is estimated that up to half the population may have died [106,107]. Numerous farms were abandoned [108,109]. Again, it is likely that abandoned farms were used as meadows and pastures by surviving farmers $[103,109]$. There is also evidence that farmers initially most dependent on outland resources were those least affected by the crisis [110].

Both these crises were associated with deteriorating climate conditions (colder, and most likely wetter). The practice of stalling livestock, as mentioned earlier, promoted by other advantages such as preventing cattle robbery (early Iron Age) and making production of milk and manure more efficient (throughout the whole period), may here ultimately turn out as advantageous for the very reason that previously was suggested as the cause for stalling: Protecting animals from adverse weather conditions [18].

The response to these crises shows that the inbuilt flexibility of infield systems promoted resilience. This flexibility was due to a resource base comprising multiple food sources, not only crops, but also livestock maintained by various outland resources, and the possibility for additional production of commodities from outlands, e.g., iron and tar, useful for trade. The flexibility of outlands thus served as a key factor for the resilience of infield systems.

\subsection{The End of Infield Systems}

The ambitions to increase agricultural production initiated during the 18th century implied an expansion of the agricultural area, and included several land reforms [71]. These processes premised the end of infield systems. The expansion of crop fields was partly executed by exploiting productive hay-meadows, and several detailed accounts of agriculture around the turn of the 18th-19th centuries show that deficiency of fodder became recognized as a problem, in turn implying deficiency in manure for fertilizing crop fields, e.g., [72,82]. This dilemma was ultimately solved by the introduction (from mid-19th century) of commercial fertilizers and leys, i.e., grass-legume mixtures cultivated on fields [111]. Thus, the old crop rotation systems were replaced by a new crop rotation 
including fodder-cropping on plowed fields maintained by commercial fertilizers, and much less fallow. Semi-natural meadows became obsolete. Meadows on clay and silty soils were turned into crop fields [112]. Less productive meadows were abandoned and transformed into forest. Some meadows close to settlements were used as enclosed pastures. Detailed studies of these land-use changes indicate that most infield grasslands were lost during the 19th and early 20th centuries $[19,113,114]$.

A parallel trend was an increased importance of the growing forestry industry, which saw forest grazing as detrimental for forest production, e.g., [115]. As forest grazing was viewed as incompatible with modern forestry, new legislation was enforced leading to a more or less total abandonment of forest grazing during the first decades of the 20th century [116].

Thus, during the 19th century the tight coupling between livestock and crop production was broken. This was followed during early 20th century by a corresponding break in the tight coupling between infields and outlands. Forests, and thereby outlands, became decoupled from agriculture. The infield systems were gone.

\section{Niche Construction and Development of Infield Systems}

The second question we ask in this paper is: To what extent were transitions and change of domesticated landscapes with infield systems the result of niche construction, involving reciprocal causation between cultural features and features of the environment and landscape?

We will first (in Section 7.1) consider the alteration of the environment of domesticated landscapes caused by human activities in infields and outlands. These alterations affected not only the resource base for humans, but also many other species, and they include effects that were not intentional. We will thereafter (in Section 7.2) consider what we regard as the key question for assessing the impact of niche construction on the infield systems: Whether there was a feedback relationship (reciprocal causation) between features of the altered environment and culture, in turn changing the way environment was altered. The cultural features in focus are aspects of management and how landscapes were perceived and organized. In Section 7.3. we briefly consider legacies of infields systems in presentday landscapes.

\subsection{Niche Construction as Alteration of the Environment}

The alterations of the environment associated with infield systems were multifaceted, and it is helpful to categorize these alterations into those manifested locally, and those which are manifested at the scale of whole landscapes. Local alterations of the environment could be, for example, construction and management of infield meadows, forest burning to promote forest grazing, or manipulation of water regimes to promote hay production at outland mires. However, one may also consider alteration of the environment with regard to the overall structure of the domesticated landscape, for example, the basic structuring of landscapes into infields and outlands, the expansion of infields associated with the emergence of villages, or the development of secondary farms located in the outland. Thus, a range of interconnected, constructed, and manipulated local environments together constitute the domesticated landscape, ultimately serving as a basis for people's subsistence. Intentionality, or goal-directed behavior [33], may seem obvious. However, the alteration of environments also includes features that were not intentional. Many other species than those directly used for hay, crops, and livestock were affected.

The most obvious alteration of the environment was within the infields, for example the deliberate disturbance necessary to create crop fields, the construction of meadows, and the transfer of nutrients from hay-meadows to crop fields. Infields were not necessarily open. Trees were maintained in wooded meadows for production of leaf-hay and for promoting production of grass-hay, e.g., [117,118]. A sparse cover of trees, and some shrubs, for example hazel (Corylus avellana), is beneficial for preventing drought, and for mobilizing soil nutrients. Furthermore, guardian trees were probably held during the Iron 
Age for their sacred role, [119] p. 36, and were actually maintained with a similar role until modern times, a remaining element of paganism almost thousand years after the transition to Christianity in Sweden.

The infield environment therefore comprised a diversity of micro-habitats which contributed to make infields suitable for a native pool of species, as this is illustrated by the exceptionally high local plant species diversity in still remaining historical meadows and pastures, e.g., $[13,14,20]$. Acknowledging that evidence is still scarce, evolutionary responses may have occurred among the favored species [120]. The high species richness in infield meadows was also influenced by structural features of the domesticated landscapes [26]. The total area of open or semi-open land increased, favoring the species pool associated with open grassland vegetation. Although the area of open landscapes had increased steadily (although periodically interrupted) since the Neolithic, e.g., [39], infield systems were associated with an agricultural expansion commencing in the early Iron Age [16], which continued throughout the whole period of the infield systems' existence (although with a few interruptions; see Section 6.3). Infield systems implied that the location of farms and the enclosed managed land became spatially stabilized. This means that the management, for example harvest of hay, took place at the same place repeatedly for a long period of time. Furthermore, dispersal of species was promoted in landscapes with many farms or villages, connected by paths for movement of people and livestock. The increased connectivity promoted colonization of these species at available infield meadows. Whether the species richness per se may have been perceived as favorable by the farmers is difficult to say, but it is probably far-fetched to consider most indirect effects on species richness as intentional.

Turning to alterations of the environment in outlands, we should recognize that these effects were spatially more extensive, and it is likely that their spatio-temporal permanency was not the same as in the infields. The use of the outland was more like a dynamic mosaic, where different parts were used different years, perhaps even with long intervals. The major use of outland was livestock grazing, and it is well established that until the late 19th century, and well into the 20th century in marginal regions, vast areas of forest were still used for livestock grazing, e.g., [83,116].

In boreal and nemoboreal forests (the vegetation zones covering most of Sweden), natural wildfires are major drivers of ecosystem processes, e.g., [121], and natural fire intervals have been estimated to be on average c. 80 years (52-160 years, depending on forest type) for northern Sweden, i.e., slightly more than $1 \%$ of the forest area burns annually [122]. Although the effects of natural wildfires could have been capitalized on for grazing livestock, fire was also used deliberately to improve grazing conditions by increasing the abundance and biomass of deciduous species such as birch (Betula spp.) and aspen (Populus tremula), and grasses such as Deschampsia flexuosa, and herbs such as Chamaenerion angustifolium [77,123,124]. Resprouting of heather (Calluna vulgaris), valuable as feed for livestock, is also promoted by fire [77,124]. Furthermore, increasing fire frequency promotes soil microbial activity, decomposition rates, and availability of soil nitrogen [121,125], effects which have generally positive effects of plant growth, and promoting grasses and herbs. Remains of charcoal may also act to reduce any effect of various allelopathic chemical compounds, i.e., compounds that have negative effects on other species' recruitment and growth [126].

Thus, burning improves the conditions for livestock grazing. But what about the direct effects of grazing per se? There are surprisingly few studies on grazing effects by livestock in forests, given the interest this old-fashioned land use currently receives from conservation biology, e.g., $[127,128]$. The paucity of studies on direct effects of forest grazing motivates some caution, but it is fairly obvious that forest grazing creates (or maintains, if the forest has been cleared by burning) relatively open forests, and that the ground flora becomes dominated by grasses and herbs. It is likely that the grazing effects are similar to those in open semi-natural grasslands, i.e., altering competitive interactions so that competitively subordinate species maintain viable populations, reducing litter 
accumulation, causing heterogeneity by disturbance due to trampling and dung deposition, and promoting a transformation from podzol to mull $[115,128]$. Up to a certain limit, these effects (and the effects of regular burning) would initiate a positive feedback process; the changing conditions due to grazing promote the productivity of feed for livestock. Although solid data is scarce, these changes promote local-scale species richness $[115,129]$. The effects on species richness may, however, be small [130], and they may depend on site productivity so that the effect may even be reversed in low-productive systems [131].

In contrast to the positive effects on local species richness in infields (which was probably mostly unintentional side-effects of management), the positive effects on species richness in outlands may have been part of the intentions behind management of grazing livestock. Of course, there were indirect side-effects as well. Other plant species were favored by burning management, for example Lycopodium [Diphasiastrum] complanatum [132] and Geranium bohemicum [133], and it would be far-fetched to interpret these effects as intended by people conducting forest burning.

What was certainly intended was the expansion of livestock management and agriculture in the outland. This expansion was manifested as a new structuring of the domesticated landscape, incorporating an increasing fraction of the outland (Figure 4), including managed hay-meadows on mires, and the establishing of secondary farms. These establishments created new focal points in the outland where infields were constructed.

\subsection{Niche Construction as Reciprocal Causation}

Viewing the whole period from the origin to the end of infield systems, it is obvious that there are several important factors for these system's development which are external, and which cannot be considered as reflecting reciprocal causation, i.e., effects emanating from responses to previous alternations of the environment in the infield systems. First and foremost, the technological innovations regarding iron production had a significant impact not only on the origin of infield systems [18], but also on their transformation. In particular, the invention of the blast furnace technology during the early Middle Age greatly increased the amount of iron available for agricultural implements such as ploughs and ards with iron shares [70], and this was one of the major factors in the transformation to communal infields with enclosed fallows. Furthermore, societal changes, the growing elite societies during the Vendel Period and the Viking Age, ultimately embedding farming in a feudallike society during the Middle Age, and the formation of nation states some centuries later, cannot be seen as reflecting reciprocal causation directly involving the infield systems. Additionally, the expanding market economy, making agricultural production integrated with other parts of society, such as towns [134] and the iron industry [45], is likely to have influenced the farmer's decisions regarding agricultural production. Although the land reforms launched in the 18th and 19th centuries were partly driven by features of infield systems (in this case, these system's inefficiency), these reforms, as with the whole agricultural revolution [71], were also inspired by a range of technological innovations concerning agricultural implements and management. To the external factors we should also add climate change, which was contributing to the two crises described earlier.

A first conclusion is therefore that niche construction involving reciprocal causation cannot be used as a single explanatory model for important parts of the general development of infield systems. External factors defined the possibilities and constraints under which infields systems originated and developed. However, as was made clear in the preceding section, infield systems were associated with numerous alterations of the environment (both direct and indirect, and intentional and unintentional), and these may have initiated processes of reciprocal causation involving aspects of culture and the environment. Thus, niche construction may operate within infield systems, in such a way that both culture and environment changed.

If we first consider niche construction involving reciprocal causation related to local alternations of environment, the clearest example concerns a continuous change of management. It is reasonable that farmers continuously adapted management practices as 
a response to their goals regarding production (food, but also other resources, such as building material, etc.). One may see farming as a continuous learning process concerning tools, management practices, and choices of crops, related to local conditions dependent on previous alternations of environment. This knowledge was transferred laterally (among farmers) and through generations. For example, through the late Iron Age and the Middle Age, the blades of scythes became successively longer [16], a direct response to a need for increasing efficiency of hay-making, and in turn affecting the outcome of the management. Another example is the knowledge behind the intricate management of wooded infield meadows, as known from the early 20th century, e.g., $[117,118,135]$ with actions conducted in a specific sequence, either yearly or less regularly, including raking during spring, choice of harvest time, and management of pollarded or coppiced trees. This knowledge is likely to have been built up over many generations and transferred across communities of farmers, and the chosen management affected the outcome of the hay-harvest, and indirectly also other species inhabiting these species-rich environments.

There are examples from the outland as well. Based on how wetland meadows located on mires were managed during early 20th century, we know of a plethora of intricate means by which the water regime was manipulated with the purpose of increasing hay production [90]. This knowledge must have accumulated over many generations, in response to the outcome of hay harvest, and as with the wooded meadows, the management altered the mire environment. Another example is the synergism between charcoal production (which opened up forest cover), and slash-and-burn cultivation followed by forest grazing, which benefitted from the favorable conditions created by the preceding cutting and burning of the forest [94]. It seems highly likely that such a combination of activities developed over time, as result of accumulated knowledge gained in response to the effects of the altered environment.

Reciprocal causation also lies behind development of cultural and environmental features manifested at whole domesticated landscapes. The use of commons was encoded in medieval laws, e.g., [74], and this cultural feature is likely to have developed in continuous interaction with the development and management of commons. For example, the change to communal infields, with fallows used as village commons, and the associated use of outland as commons, did not only change the infield environment, as it also had profound effects of social relations within villages. Although the laws where these social relations (or parts of them) were encoded certainly were formed for many other reasons as well, it is possible to causally connect various aspects of social relationships with the altering of environments. However, it is difficult to identify "what is the hen and what is the egg". For example: Were laws reflecting social relations resulting from a new form of communal management? Or, were communal management a result of social relations enforced by laws? The answer is that none of these alternatives is fully correct. The causality worked in both directions, just as implied in theory of human niche construction.

Another example concerns secondary farms. Irrespective of the outcome of the debate about when secondary farms first appeared, this form of transhumance is interpreted as a response to a poorly productive forest environment, e.g., $[85,96]$. In order to avoid over-exploitation of the near surroundings of the infields, secondary farms inhabited summertime were located at some distance from the main farm. Thus, out-located small infield systems were constructed in the outland, and with this came environmental alterations due to forest grazing and meadow management (as described in the previous section). During the centuries preceding the abandonment of most secondary farms in the early 20th century, these were used particularly for dairy production, butter, and cheese, available for trade, thus contributing to the farming economy [96]. There are several cultural features associated with outland use specifically related to secondary farms. Their management was largely a female activity, including not only handling milking and dairy products, but also transporting and herding of cattle, in turn creating a mind-map of large tracts of the outland landscapes, manifested as paths, resting stones, and messages carved into trees $[136,137]$. Again, we have a complex of aspects of both culture and environment, 
obviously causally related to each other, but where it is difficult to define a direction of the causal arrow. The causality worked in both directions.

So far, we have dealt with reciprocal relationships where the components of culture and environment in a sense enforce each other, i.e., the relationships are allowing, for example: "Better tools and innovative management lead to increased hay harvest, increased amount of manure, increased crop production, in turn promoting innovation etc.". However, niche construction may also concern constraining relationships, where the altered environment is pushed to a limit and where the cultural response initiates a more drastic shift in the future alteration of the environment. This can be considered as a trap for the niche constructing agent (humans, in this case), and it may lead to consequences not foreseen or intended when the process started [138]. The events preceding the end of infield systems described above in Section 6.4 is an example. The deficiencies of infield systems to satisfy the need for agricultural products encouraged expansion of the crop field area. This was done partly by transforming productive infield meadows to crop fields, which in turn led to a lack of livestock fodder and ultimately manure, bouncing back to reduced crop production. The infield systems were caught in a trap. The solution that ultimately came implied the initial steps to abandon the infield systems, by replacing manure with commercial fertilizers (again an external factor), thus decoupling livestock from crop production. This process also involves reciprocal causation, but associated with a shift in the altered environment such that one component of the infield systems, managed meadows, disappeared and was replaced by leys.

Finally, we remark on two speculative examples of how infield systems may have influenced people's conceptions. In Old Norse mythology, the place where humans live was named Midgard (Old Norse: Miðgarðr). Outside Midgard was Utgard (Old Norse: Útgarðr), the place beyond the world of humans, inhabited by trolls and evil powers [44]. It has for long been speculated that this cosmology is a reflection of infields and outland, although the idea has also been questioned [119]. Linguistically it makes sense, as gardr literally means enclosed space, i.e., infields. However, as we have seen, the outland was far from a place beyond the world of humans, but rather a key to the functioning of the infield system, and a major contributor to the resilience of the system. Therefore, even if the Iron Age mythological universe was divided into Midgard and Utgard, and this somehow corresponded to a landscape with infields and outland, it seems unlikely that people in their everyday life considered the outland as dangerous and beyond their homeland.

The second example concerns the Old Norse mythological world-tree, the ash $Y g$ gdrasill [119]. Ash (Fraxinus excelsior) is probably the best tree to have in wooded meadows. World-trees exist in many different cultures [119]. Of course, it is impossible to know, but one may wonder whether the choice of species for the world-tree in the Old Norse culture was a coincidence.

In conclusion, the development of infield systems, from their origin in the early Iron Age and until their final demise during the 19th century, involves a range of inter-related changes affecting both culture and the environment, and where the causalities are reciprocal. Viewing the changes in a temporal sequence, they work alternately in either direction, or simultaneously in both directions (Figure 5). Niche construction processes are thus essential for an understanding of the development of infield systems, even though, as remarked above, external factors must be considered as well. 


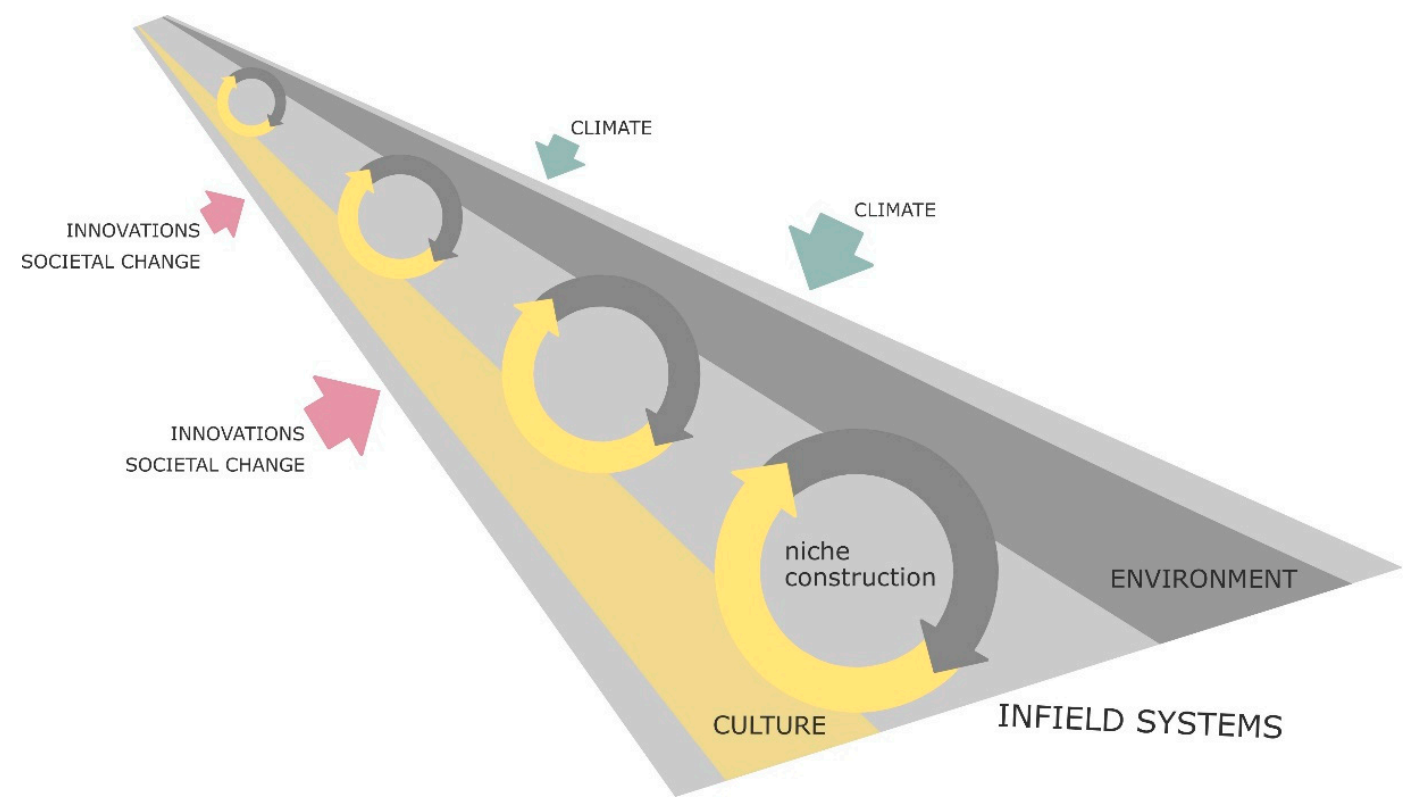

Figure 5. Visualization of niche construction through time in infield systems.

\subsection{Legacies of Infield Systems and Current Niche Construction}

The infield systems are gone, but they have left plenty of legacies. For example, in the Swedish countryside, many farms have maintained their Iron Age location, e.g., [64], and they often have pagan names, referring to Old Norse gods such as Odin, Thor, Freyr, and Freyja. Traveling through the landscape thus means that one experiences the basic spatial structure of the former infield systems. Another kind of legacy is the public rights to access land outside farms and private gardens that is special for the Nordic countries (except Denmark), a legacy that has been maintained despite the abandonment of outland commons in the 19th century.

Focusing on the ecological memory, i.e., the alterations of environment which still remain visible in present-day landscapes, the most obvious and common legacy is what is today termed semi-natural grasslands [14]. This term is a bit vague, but generally it means grasslands (including those with a sparse cover of trees, such as wooded meadows) which previously were used for production of livestock fodder or for grazing, and which have no obvious traces of previous fertilization and plowing. Semi-natural grasslands are usually very species-rich, and are nowadays a concern mainly for conservation biology, but to some extent also for managing and preserving cultural heritage. About a third of RedListed species in Sweden is associated with remains of old agricultural landscapes [139]. There are no exact data on the present-day extent of semi-natural grasslands in Sweden, but it is estimated that between 255,000 and 270,000 hectares of valuable semi-natural grasslands remain, of which semi-natural meadows (still managed by mowing) are below 10,000 hectares $[140,141]$. Even though many of these grasslands have a background as semi-natural meadows, most of them are currently maintained by livestock grazing, sheep or cattle. Forest grazing more or less ceased during the 20th century, but is again used for conservation purposes. Currently, about 16,000 hectares in Sweden are subjected to forest grazing, excluding those associated with still maintained secondary farms [127].

It is worth noting that features resulting from historical niche construction processes, in the modern society have been reinterpreted to values related to modern conceptions such as ecosystem services, cultural heritage, aesthetics, and species richness. This implies a new kind of niche construction dynamics, a reciprocal causation involving various conservation programs and subsidies, interacting with the effects these programs have on these different values [142]. Although it is unclear whether current conservation programs will be successful in the long-term, and maintain the perceived values of the legacies of 
former infield systems, e.g., [141,143], human niche construction is still ongoing, but by different means.

\section{Concluding Remarks}

The main conclusion from this examination of the historical ecology of Scandinavian infield systems is that the theory of human niche construction contributes to an understanding of how domesticated landscapes with these infield systems developed and changed during the two millennia of their existence. The essential components of human niche construction, alterations of the environment by humans, cultural response to these alternations, and an ongoing interaction between the processes of change in environment and culture, a reciprocal causation, are applicable to several of the environmental and cultural features of infield systems. However, it was also clear that human niche construction is insufficient as a model for several of the major transitions and changes that occurred in the infield systems. External factors, which were not directly involved in the reciprocal causation, had decisive impacts on the development and change. Examples include innovations such as blast furnace technology for iron production, the rise of an elite society ultimately leading to feudalism and formation of nation states, availability of commercial fertilizers, and the growth of a modern forestry industry.

A second conclusion stems from the fact that infield systems proved exceptionally resilient despite several severe crises affecting farming and people's livelihood. Twice during these two millennia, in the 6th and in the 14th centuries, possibly as much as half the human population succumbed due to famine and plague, and large fractions of settlements were abandoned. The inherent flexibility in infield systems, in particular the diversified use of outlands, enabling survival of livestock, and use of a manifold of resources, was vital for people's survival. Ultimately however, the infield systems turned out to be insufficient for feeding a growing human population, and during a period of around hundred years, infield systems were replaced with the basic landscape infrastructure characteristic for the modern industrial society: An agriculture focusing on managed fields with both crops and fodder and maintained by artificial fertilizers and fossil fuel, and a forestry industry producing timber and pulp.

The infield systems have left many legacies, both in terms of cultural heritage, beautiful landscapes, and species-rich environments, particularly semi-natural grasslands. Currently, considerable research efforts are allocated to various issues relating to aspects of what formerly were infield systems, for example concerning conservation biology, species diversity, ecosystem services, sustainable food production, and carbon sequestration. Deeper insights into the historical ecology of infield systems would therefore seem to be in order, and hopefully our examination of the niche construction processes behind this old farming system will prove valuable.

Author Contributions: Conceptualization, O.E., M.A. and K.-J.L.; writing-original draft preparation, O.E.; writing-review and editing, O.E., M.A. and K.-J.L.; visualization, M.A.; funding acquisition, K.-J.L. All authors have read and agreed to the published version of the manuscript.

Funding: This is a contribution from the project 'Contesting marginality: the boreal forest of inland Scandinavia and the worlds outside, AD 1-1500' (UTMA), funded by the Swedish Research Council (2017-01483).

Institutional Review Board Statement: Not applicable.

Informed Consent Statement: Not applicable.

Data Availability Statement: Not applicable.

Acknowledgments: We are grateful to A.H., E.S. and D.L. in the UTMA-project for inspiring discussions.

Conflicts of Interest: The authors declare no conflict of interest. 


\section{References}

1. Crumley, C.L. Historical ecology: A multidimensional ecological orientation. In Historical Ecology: Cultural Knowledge and Changing Landscapes; Crumley, C.L., Ed.; School of American Research Press: Santa Fe, NM, USA, 1994; pp. 1-16.

2. Crumley, C.L.; Lennartsson, T.; Westin, A. (Eds.) Issues and Concepts in Historical Ecology: The Past and Future of Landscapes and Regions; Cambridge University Press: Cambridge, UK, 2018.

3. Balée, W. The research program of historical ecology. Annu. Rev. Anthropol. 2006, 35, 75-98. [CrossRef]

4. Szabó, O. Historical ecology: Past, present and future. Biol. Rev. 2015, 90, 997-1014. [CrossRef] [PubMed]

5. Meyer, W.J.; Crumley, C.L. Historical ecology: Using what works to cross the divide. In Atlantic Europe in the First Millennium BC. Crossing the Divide; Moore, T., Armada, L., Eds.; Oxford University Press: Oxford, UK, 2011; pp. 109-134.

6. Leuridan, B.; Froeyman, A. On lawfulness in history and historiography. Hist. Theory 2012, 51, 172-192. [CrossRef]

7. Odling-Smee, F.J.; Laland, K.N.; Feldman, M.W. Niche Construction: The Neglected Process in Evolution; Princeton University Press: Princeton, NJ, USA, 2003.

8. Kendal, J.; Tehrani, J.J.; Odling-Smee, J. Human niche construction in interdisciplinary focus. Philos. Trans. R. Soc. Lond. B 2011, 366, 785-792. [CrossRef]

9. Eriksson, O.; Ekblom, A.; Lane, P.; Lennartsson, T.; Lindholm, K.-J. Concepts for integrated research in historical ecology. In Issues and Concepts in Historical Ecology: The Past and Future of Landscapes and Regions; Crumley, C.L., Lennartsson, T., Westin, A., Eds.; Cambridge University Press: Cambridge, UK, 2018; pp. 145-181.

10. Øye, I. Settlement patterns and field systems in medieval Norway. Landsc. Hist. 2009, 30, 37-54. [CrossRef]

11. Widgren, M. Climate and causation in the Swedish Iron Age: Learning from the present to understand the past. Geografisk Tidskr. Dan. J. Geogr. 2012, 112, 126-134. [CrossRef]

12. Berglund, B.E.; Kitagawa, J.; Lagerås, P.; Nakamura, K.; Sasaki, N.; Yasuda, Y. Traditional farming landscapes for sustainable living in Scandinavia and Japan: Global revival through the Satoyama initiative. Ambio 2014, 43, 559-578. [CrossRef]

13. Plieninger, T.; Hartel, T.; Martín-López, B.; Beaufoy, G.; Bergmeier, E.; Kirby, K.; Montero, M.J.; Moreno, G.; Oteros-Rozas, E.; van Uytvanck, J. Wood-pastures of Europe: Geographic coverage, social-ecological values, conservation management, and policy implications. Biol. Conserv. 2015, 190, 70-79. [CrossRef]

14. Eriksson, O.; Cousins, S.A.O. Historical landscape perspectives on grasslands in Sweden and the Baltic region. Land 2014, 3, 300-321. [CrossRef]

15. Eriksson, $\mathrm{O}$. What is biological cultural heritage and why should we care about it? An example from Swedish rural landscapes and forests. Nat. Conserv. 2018, 28, 1-32. [CrossRef]

16. Pedersen, E.A.; Widgren, M. Agriculture in Sweden, 800 BC-AD 1000. In The Agrarian History of Sweden: From 4000 BC to AD 2000; Myrdal, J., Morell, M., Eds.; Nordic Academic Press: Lund, Sweden, 2011; pp. 46-71.

17. Eriksson, O.; Arnell, M. Niche construction, entanglement and landscape domestication in Scandinavian infield systems. Landsc. Res. 2017, 42, 78-88. [CrossRef]

18. Eriksson, O. Origin and development of managed meadows in Sweden: A review. Rural Landsc. Soc. Environ. Hist. 2020, 7, 1-23. [CrossRef]

19. Cousins, S.A.O.; Auffret, A.G.; Lindgren, J.; Tränk, L. Regional-scale land-cover change during the 20th century and its consequences for biodiversity. Ambio 2015, 44S1, 17-27. [CrossRef] [PubMed]

20. Cousins, S.A.O.; Eriksson, O. The influence of management history and habitat on plant species richness in a rural hemiboreal landscape, Sweden. Landsc. Ecol. 2002, 17, 517-529. [CrossRef]

21. Lindborg, R.; Eriksson, O. Historical landscape connectivity affects present plant species richness. Ecology 2004, 85, 1840-1845. [CrossRef]

22. Gustavsson, E.; Lennartsson, T.; Emanuelsson, M. Land use more than 200 years ago explains current grassland plant diversity in a Swedish agricultural landscape. Biol. Conserv. 2007, 138, 47-59. [CrossRef]

23. Pärtel, M.; Helm, A.; Reitalu, T.; Liira, J.; Zobel, M. Grassland diversity related to the Late Iron Age human population density. J. Ecol. 2007, 95, 574-582. [CrossRef]

24. Johansson, L.J.; Hall, K.; Prentice, H.C.; Ihse, M.; Reitalu, T.; Sykes, M.T.; Kindström, M. Semi-natural grassland continuity, long-term land-use change and plant species richness in an agricultural landscape on Öland, Sweden. Landsc. Urban Plan. 2008, 84, 200-211. [CrossRef]

25. Reitalu, T.; Johansson, L.J.; Sykes, M.T.; Hall, K.; Prentice, H.C. History matters: Village distances, grazing and grassland species diversity. J. Appl. Ecol. 2010, 47, 1216-1224. [CrossRef]

26. Eriksson, O. Species pools in cultural landscapes: Niche construction, ecological opportunity and niche shifts. Ecography 2013, 36, 403-413. [CrossRef]

27. Odling-Smee, J.; Erwin, D.H.; Palkovacs, E.P.; Feldman, M.W.; Laland, K.N. Niche construction theory: A practical guide for ecologists. Q. Rev. Biol. 2013, 88, 3-28. [CrossRef] [PubMed]

28. Buskell, A. Reciprocal causation and the extended evolutionary synthesis. Biol. Theor. 2019, 14, 267-279. [CrossRef]

29. Smith, B.D. General patterns of niche construction and the management of 'wild' plant and animal resources by small-scale pre-industrial societies. Philos. Trans. R. Soc. B 2011, 366, 836-848. [CrossRef] [PubMed]

30. Laland, K.N.; O’Brien, M.J. Cultural niche construction: An introduction. Biol. Theor. 2012, 6, 191-202. [CrossRef] 
31. Mesoudi, A. Cultural Evolution: How Darwinian Theory Can Explain Human Culture and Synthesize the Social Sciences; University of Chicago Press: Chicago, IL, USA, 2011.

32. Smith, B.D. Neo-Darwinism, niche construction theory, and the initial domestication of plants and animals. Evol. Ecol. 2016, 30, 307-324. [CrossRef]

33. Zeder, M. Domestication as a model system for niche construction theory. Evol. Ecol. 2016, 30, 325-348. [CrossRef]

34. Ellis, E.C. Ecology in an anthropogenic biosphere. Ecol. Monogr. 2015, 85, 287-331. [CrossRef]

35. Boivin, N.L.; Zeder, M.A.; Fuller, D.Q.; Crowther, A.; Larson, G.; Erlandson, J.M.; Denham, T.; Petraglia, M.D. Ecological consequences of human niche construction: Examining long-term anthropogenic shaping of global species distributions. Proc. Natl. Acad. Sci. USA 2016, 113, 6388-6396. [CrossRef]

36. Widgren, M. Landscape research in a world of domesticated landscapes: The roles of values, theory, and concepts. Quat. Int. 2012, 251, 117-124. [CrossRef]

37. Hodder, I. Things and the slow Neolithic: The Middle Eastern transformation. J. Archaeol. Meth. Theor. 2018, 25, 155-177. [CrossRef]

38. Hodder, I. Entangled: An Archaeology of the Relationships between Humans and Things; Wiley-Blackwell: Chichester, UK, 2012.

39. Berglund, B.E.; Gaillard, M.-J.; Björkman, L.; Persson, T. Long-term changes in floristic diversity in southern Sweden: Palynological richness, vegetation dynamics and land-use. Veg. Hist. Archaeobotany 2008, 17, 573-583. [CrossRef]

40. Cui, Q.-Y.; Gaillard, M.-J.; Lemdahl, G.; Stenberg, L.; Sugita, S.; Zernova, G. Historical land-use and landscape change in southern Sweden and implications for present and future biodiversity. Ecol. Evol. 2014, 4, 3555-3570. [CrossRef] [PubMed]

41. Grabowski, R. Changes in cereal cultivation during the Iron Age in southern Sweden: A compilation and interpretation of the archaeobotanical material. Veg. Hist. Archaeobot. 2011, 20, 479-494. [CrossRef]

42. Gaillard, M.-J.; Birks, H.J.B.; Emanuelsson, E.; Karlsson, E.; Lagerås, P.; Olausson, D. Application of modern pollen/land-use relationships to the interpretation of pollen diagrams-reconstructions of land-use history in South Sweden. Rev. Palaeobot. Palynol. 1994, 82, 47-73. [CrossRef]

43. Zachrisson, T. The background of the odal rights: An archaeological discussion. Danish J. Archaeol. 2017, 6, 118-132. [CrossRef]

44. Price, N. The Children of Ash E Elm: A History of the Vikings; Allen Lane: London, UK, 2020.

45. Myrdal, J. Farming and feudalism 1000-1700. In The Agrarian History of Sweden. From 4000 BC to AD 2000; Myrdal, J., Morell, M., Eds.; Nordic Academic Press: Lund, Sweden, 2011; pp. 72-117.

46. Svedjemo, G. Landscape Dynamics—Spatial Analyses of Villages and Farms on Gotland AD 200-1700. Ph.D. Thesis, Uppsala University, Uppsala, Sweden, 2014.

47. Widgren, M. Settlement and Farming Systems in the Early Iron Age. A study of Fossil Agrarian Landscapes in Östergötland, Sweden. Ph.D. Thesis, Stockholm University, Stockholm, Sweden, 1983.

48. Emanuelsson, U. The Rural Landscapes of Europe: How Man Has Shaped European Nature; The Swedish Research Council Formas: Stockholm, Sweden, 2009.

49. Lennartsson, T.; Westin, A.; Iuga, A.; Jones, E.; Madry, S.; Murray, S.; Gustavsson, E. The meadow is the mother of the field. Comparing transformations in hay production in three European agroecosystems. Martor 2016, 21, $103-126$.

50. Hjärthner-Holdar, E.; Grandin, L.; Sköld, K.; Svensson, A. By who, for whom? Landscape, process and economy in the bloomery iron production AD 400-1000. J. Archaeol. Ancient Hist. 2018, 21, 1-50.

51. Løvschal, M.; Holst, M.K. Repeating boundaries-repertoires of landscape regulations in southern Scandinavia in the Late Bronze Age and Pre-Roman Iron Age. Dan. J. Archaeol. 2014, 3, 95-118. [CrossRef]

52. McClure, S.B. The pastoral effect: Niche construction, domestic animals, and the spread of farming in Europe. Curr. Anthropol. 2015, 56, 901-910. [CrossRef]

53. Kristiansen, K.; Larsson, T.B. The Rise of Bronze Age Society: Travels, Transmissions and Transformations; Cambridge University Press: Cambridge, UK, 2005.

54. Holst, M.K.; Rasmussen, M. Herder communities: Longhouses, cattle and landscape organization in the Nordic Early and Middle Bronze Age. In Counterpoint: Essays in Archaeology and Heritage Studies in Honour of Professor Kristian Kristiansen; Bergerbrant, S., Sabatini, S., Eds.; Archaeopress: Oxford, UK, 2013; pp. 99-110.

55. Myrdal, J. Elisendorf and cattle-breeding in the Northwestern European Iron Age. Fornvännen 1984, 79, 73-92. (In Swedish with English Summary)

56. Zimmermann, W.H. Why was cattle-stalling introduced in prehistory? The significance of byre and stable and of outwintering In Settlement and Landscape. Proceedings of a Conference in Aarhus, Denmark, 4-7 May 1998; Fabech, C., Ringtved, J., Eds.; Aarhus University Press: Aarhus, Denmark, 1999; pp. 301-318.

57. Bogaard, A.; Fraser, R.; Heaton, T.H.E.; Wallace, M.; Vaiglova, P.; Charles, M.; Jones, G.; Evershed, R.P.; Styring, A.K.; Andersen, N.H.; et al. Crop manuring and intensive land management by Europe's first farmers. Proc. Natl. Acad. Sci. USA 2013, 110, 12589-12594. [CrossRef] [PubMed]

58. Welinder, S. Early farming households, 3900-800 BC. In The Agrarian History of Sweden: 4000 BC to AD 2000; Myrdal, J., Morell, M., Eds.; Nordic Academic Press: Lund, Sweden, 2011; pp. 18-45.

59. Nielsen, N.H.; Kristiansen, S.M.; Ljungberg, T.; Enevold, R.; Løvschal, M. Low and variable: Manuring intensity in Danish Celtic fields. J. Archaeol. Sci. Rep. 2019, 27, 101955. [CrossRef] 
60. Gron, K.J.; Rowley-Conwy, P. Herbivore diet and the anthropogenic environment of early farming in southern Scandinavia. Holocene 2017, 27, 98-109. [CrossRef]

61. Zachrisson, T. The Odal and its manifestation in the landscape. Curr. Swed. Archaeol. 1994, 2, $219-238$.

62. Earle, T. Archaeology, property, and prehistory. Annu. Rev. Anthropol. 2000, 29, 39-60. [CrossRef]

63. Herschend, F. The Early Iron Age in South Scandinavia: Social Order in Settlement and Landscape; Occasional Papers in Archaeology 46; Uppsala University: Uppsala, Sweden, 2009.

64. Göthberg, H. Changing settlements: Uppland from the end of the Late Bronze Age to the Early Middle Ages. Ph.D. Thesis, Uppsala University, Uppsala, Sweden, 2000. (In Swedish with English Summary)

65. Welinder, S.; Pedersen, E.A.; Widgren, M. Jordbrukets första femtusen år, 4000 f.Kr.-1000 e.Kr; Natur och Kultur/LTs Förlag: Stockholm, Sweden, 1998. (In Swedish)

66. Nielsen, N.H.; Dalsgaard, K. Dynamics of Celtic fields-A geoarchaeological investigation of Øster Lem Hede, Western Jutland, Denmark. Geoarchaeology 2017, 32, 414-434. [CrossRef]

67. Ericsson, A.; Strucke, U. Att hägna med stenmurar: En studie av stensträngsbygder i Mälarlandskapen. In Hem till Jarlabanke: Jord, makt och evigt liv i östra Mälardalen under järnålder och medeltid; Olausson, M., Ed.; Historiska Media: Lund, Sweden, 2008; pp. 48-90. (In Swedish)

68. Sinclair, P.; Moen, J.; Crumley, C.L. Historical ecology and the longue durée. In Issues and Concepts in Historical Ecology: The Past and Future of Landscapes and Regions; Crumley, C.L., Lennartsson, T., Westin, A., Eds.; Cambridge University Press: Cambridge, UK, 2018; pp. 13-40.

69. af Geijerstam, J.; Nisser, M. (Eds.) Swedish Mining and Metalworking. National Atlas of Sweden; Norstedts Förlagsgrupp: Stockholm, Sweden, 2011.

70. Karlsson, C. Lost iron-Requirement and Consumption of Iron and Steel in Agriculture in Medieval Sweden. Ph.D. Thesis, Swedish University of Agricultural Sciences, Uppsala, Sweden, 2015. (In Swedish with English Summary)

71. Gadd, C.-J. The agricultural revolution in Sweden 1700-1870. In The Agrarian History of Sweden from 4000 BC to AD 2000; Myrdal, J., Morell, M., Eds.; Nordic Academic Press: Lund, Sweden, 2011; pp. 118-164.

72. Nyström, L.; Hallberg, E. Two parallel systems: The political economy of enclosures and open fields on the plains of Västergötland, western Sweden, 1805-1865. Hist. Agrar. 2018, 76, 85-122. [CrossRef]

73. Sandström, E.; Ekman, A.-K.; Lindholm, K.-J. Commoning in the periphery-The role of the commons for understanding rural continuities and change. Int. J. Comm. 2017, 11, 508-531. [CrossRef]

74. Lindholm, K.-J.; Sandström, E.; Ekman, A.-K. The archaeology of the commons. J. Archaeol. Ancient Hist. 2013, 10, 1-49.

75. Magnusson, G. Prehistoric and Medieval Iron Industry in the Province of Jämtland. Ph.D. Thesis, Stockholm University, Stockholm, Sweden, 1986. (In Swedish with English Summary)

76. Hennius, A. Viking Age tar production and outland exploitation. Antiquity 2018, 92, 1349-1361. [CrossRef]

77. Groven, R.; Niklasson, M. Anthropogenic impact of past and present fire regimes in a boreal forest landscape of southeastern Norway. Can. J. For. Res. 2005, 35, 2719-2726. [CrossRef]

78. Granström, A.; Niklasson, M. Potentials and limitations for human control over historic fire regimes in the boreal forest. Philos. Trans. R. Soc. B 2008, 363, 2353-2358. [CrossRef] [PubMed]

79. Rolstad, J.; Blanck, Y.-L.; Storaunet, K.O. Fire history in a western Fennoscandian boreal forest as influenced by human land use and climate. Ecol. Monogr. 2017, 87, 219-245. [CrossRef]

80. Niklasson, M.; Granström, A. Numbers and sizes of fires: Long-term spatially explicit fire history in a Swedish boreal landscape. Ecology 2000, 81, 1484-1499. [CrossRef]

81. Niklasson, M.; Drakenberg, B. A 600-year tree-ring fire history from Norra Kvills National Park, southern Sweden: Implications for conservation strategies in the hemiboreal zone. Biol. Conserv. 2001, 101, 63-71. [CrossRef]

82. Gustafsson, M. Bondesamhällets omvandling i Nordvästskåne. Bjärehalvöns agrara utveckling under 1700- och 1800-talet; The Royal Swedish Academy of Agriculture and Forestry: Stockholm, Sweden, 2006. (In Swedish)

83. Nilsson, S.G. The changing structure and tree composition in the traditionally grazed forests in the parish of Stenbrohult, S. Sweden. Sv. Bot. Tidskr. 2006, 100, 393-412. (In Swedish with English Summary)

84. Hyenstrand, Å. Iron and iron economy in Sweden. In Iron and Man in Prehistoric Sweden; Clarke, H., Ed.; LTs Förlag: Stockholm, Sweden, 1979; pp. 134-156.

85. Magnusson, G.; Segerström, U. Life in a forest community: When did settlement of south Norrland begin? Bebyggelsehistorisk Tidskrift 2009, 57, 7-25. (In Swedish with English Summary)

86. Lindholm, K.-J.; Ljungkvist, J. The bear in the grave: Exploitation of top predator and herbivore resources in first millennium Sweden—first trends from a long-term research project. Eur. J. Archaeol. 2016, 19, 3-27. [CrossRef]

87. Hennius, A. Towards a refined chronology of prehistoric pitfall hunting in Sweden. Eur. J. Archaeol. 2020, 23, 530-546. [CrossRef]

88. Karlsson, H.; Emanuelsson, M.; Segerström, U. The history of a farm-shieling system in the central Swedish forest region. Veg. Hist. Archaeobot. 2010, 19, 103-119. [CrossRef]

89. Segerström, U.; Emanuelsson, M. Extensive forest grazing and hay-making on mires—vegetation changes in south-central Sweden due to land use since Medieval times. Veg. Hist. Archaeobot. 2002, 11, 181-190. [CrossRef]

90. Elveland, J. Wet hay-meadows in northern Sweden-their history and present status. Sv. Bot. Tidskr. 2015, 109, 292-336. (In Swedish with English Summary) 
91. Slotte, H. Harvesting of leaf-hay shaped the Swedish landscape. Landsc. Ecol. 2001, 16, 691-702. [CrossRef]

92. Wedin, M. Den skogsfinska kolonisationen i Alfta, Bollnäs och Hanebo; Finnbygdens Förlag: Falun, Sweden, 2004. (In Swedish)

93. Vestbö-Franzén, Å. Farming by fire in north-eastern Småland, Sweden. Bebyggelsehistorisk Tidskrift 2019, 77, 8-21.

94. Emanuelsson, M.; Segerström, U. Medieval slash-and-burn cultivation: Strategic or adapted land use in the Swedish mining district. Environ. Hist. 2002, 8, 173-196. [CrossRef]

95. Von Stedingk, H.; Baudou, E. Capitalism in central Norrland, Sweden, during the Iron Age. Curr. Swed. Archaeol. 2006, 14, 177-198.

96. Larsson, J. Summer Farms in Sweden 1550 to 1920: An Important Element in North Sweden's Agricultural System. Ph.D. Thesis, Swedish University of Agricultural Sciences, Uppsala, Sweden, 2009. (In Swedish with English Summary)

97. Øye, I. Technology, land use and transformation in Scandinavian landscapes, c. 800-1300 AD. In Economic Archaeology: From Structure to Performance in European Archaeology; Kerig, T., Zimmermann, A., Eds.; Habelt: Bonn, Germany, 2013 ; pp. $295-309$.

98. Büntgen, U.; Myglan, V.S.; Ljungqvist, F.C.; McCormick, M.; Di Cosmo, N.; Sigl, M.; Jungclaus, J.; Wagner, S.; Krusic, P.J.; Esper, J.; et al. Cooling and societal change during the Late Antique Little Ice Age from 536 to around 600 AD. Nat. Geosci. 2016, 9, 231-236. [CrossRef]

99. Zachrisson, T. Property and honour: Social change in central Sweden, 200-700 AD mirrored in the area around Old Uppsala. In Archäologie in Schleswig, Sachsensymposium Haderslev 2010; Boye, L., Ed.; Wachholtz Verlag: Neumünster, Germany, 2011; pp. 141-156.

100. Iversen, F. Estate division: Social cohesion in the aftermath of AD 536-7. In The Agrarian Life of the North 2000 BC-AD 1000. Studies in Rural Settlement and Farming in Norway; Iversen, F., Petersson, H., Eds.; Portal: Kristiansand, Norway, 2016; pp. 41-75.

101. Beronius-Jörpeland, L.; Göthberg, H. Gårdar och människor i ett långt tidsperspektiv—temasyntes. In At Upsalum—Människor och landskapande. Utbyggnad av ostkustbanan genom Gamla Uppsala; Beronius-Jörpeland, L., Göthberg, H., Seiler, A., Wikborg, J., Eds.; Statens Historiska Museer: Stockholm, Sweden, 2017; pp. 173-185. (In Swedish)

102. Gräslund, B.; Price, N. Twilight of the gods? The 'dust veil event' of AD 536 in a critical perspective. Antiquity 2012, 86, 428-443. [CrossRef]

103. Löwenborg, D. An Iron Age shock doctrine: Did the AD 536-7 event trigger large-scale social changes in the Mälaren valley area? J. Archaeol. Ancient Hist. 2012, 4, 1-28.

104. Oinonen, M.; Alenius, T.; Arppe, L.; Bocherens, H.; Etu-Sihvola, H.; Helama, S.; Huhtamaa, H.; Lahtinen, M.; Mannermaa, K.; Onkamo, P.; et al. Buried in water, burdened by nature-Resilience carried the Iron Age people through Fimbulwinter. PLoS ONE 2020, 15, e0231787. [CrossRef]

105. Wanner, H.; Beer, J.; Bütikofer, J.; Crowley, T.J.; Cubasch, U.; Flückiger, J.; Goosse, H.; Grosjean, M.; Joos, F.; Kaplan, J.O.; et al. Mid- to Late Holocene climate change: An overview. Q. Sci. Rev. 2008, 27, 1791-1828. [CrossRef]

106. Myrdal, J. Digerdöden, pestvågor och ödeläggelse. Ett perspektiv på senmedeltidens Sverige; Sällskapet Runica et Mediævalia: Stockholm, Sweden, 2003. (In Swedish)

107. Berglund, B.; Eriksson, K.; Holm, I.; Karlsson, H.; Karlsson, J.; Pettersson, S.; Sundberg, A.; Ulfheim, B.; Welinder, S. The historical archaeology of the medieval crisis in Scandinavia. Curr. Swed. Archaeol. 2009, 17, 55-78.

108. Lagerås, P. The Ecology of Expansion and Abandonment: Medieval and Post-Medieval Land-Use and Settlement Dynamics in a Landscape Perspective; Swedish National Heritage Board: Stockholm, Sweden, 2007.

109. Antonsson, $\mathrm{H}$. The extent of farm desertion in central Sweden during the late medieval agrarian crisis: Landscape as a source. J. Hist. Geogr. 2009, 35, 619-641. [CrossRef]

110. Svensson, E. Crisis or transition? Risk and resilience during the Late Medieval agrarian crisis. In Settlement Change across Medieval Europe; Brady, N., Theune, C., Eds.; Sidestone Press: Leiden, The Netherlands, 2019; pp. 171-181.

111. Morell, M. Agriculture in industrial society 1870-1945. In The Agrarian History of Sweden. From 4000 BC to AD 2000; Myrdal, J., Morell, M., Eds.; Nordic Academic Press: Lund, Sweden, 2011; pp. 165-213.

112. Cousins, S.A.O. Landscape history and soil properties affect grassland decline and plant species richness in rural landscapes. Biol. Conserv. 2009, 142, 2752-2758. [CrossRef]

113. Cousins, S.A.O. Analysis of land-cover transitions based on 17th and 18th century cadastral maps and aerial photographs. Landsc. Ecol. 2001, 16, 41-54. [CrossRef]

114. Cousins, S.A.O.; Eriksson, O. After the hotspots are gone: Land use history and grassland plant species diversity in a strongly transformed agricultural landscape. Appl. Veg. Sci. 2008, 11, 365-374. [CrossRef]

115. Steen, E. Effects of Grazing on Swedish Vegetation; Statens Jordbruksförsök Meddelande nr 89: Uppsala, Sweden, 1958. (In Swedish with English Summary)

116. Kardell, Ö. Swedish forestry, forest pasture grazing by livestock, and game browsing pressure since 1900. Environ. Hist. 2016, 22, 561-587. [CrossRef]

117. Hæggström, C.-A. Vegetation and soil of the wooded meadows in Nåtö, Åland. Acta Bot. Fenn. 1983, $120,1-66$.

118. Hæggström, C.-A. Pollard meadows: Multiple use of human-made nature. In The Ecological History of European Forests; Kirby, K.J., Watkins, C., Eds.; CAB International: Wallingford, UK, 1998; pp. 33-41.

119. Andrén, A. Tracing Old Norse Cosmology: The World Tree, Middle Earth, and the Sun in Archaeological Perspectives; Nordic Academic Press: Lund, Sweden, 2014. 
120. MacDougall, A.S.; McCune, J.L.; Eriksson, O.; Cousins, S.A.O.; Pärtel, M.; Firn, J.; Hierro, J.L. The Neolithic plant invasion hypothesis: The role of preadaptation and disturbance in grassland invasion. New Phytol. 2018, 220, 94-103. [CrossRef]

121. Nilsson, M.-C.; Wardle, D.A. Understory vegetation as a forest ecosystem driver: Evidence from the northern Swedish boreal forest. Front. Ecol. Environ. 2005, 3, 421-428. [CrossRef]

122. Zackrisson, O. Influence of forest fires on the North Swedish boreal forest. Oikos 1977, 29, 22-32. [CrossRef]

123. Schimmel, J.; Granström, A. Fire severity and vegetation response in the boreal Swedish forest. Ecology 1996, 77, 1436-1450. [CrossRef]

124. Gustafsson, L.; Berglind, M.; Granström, A.; Grelle, A.; Isacsson, G.; Kjellander, P.; Larsson, S.; Lindh, M.; Pettersson, L.B.; Strengbom, J.; et al. Rapid ecological response and intensified knowledge accumulation following a north European mega-fire. Scand. J. For. Res. 2019, 34, 234-253. [CrossRef]

125. Wardle, D.A.; Hörnberg, G.; Zackrisson, O.; Kalela-Brundin, M.; Coomes, D.A. Long-term effects of wildfire on ecosystem properties across an island area gradient. Science 2003, 300, 972-975. [CrossRef]

126. Wardle, D.A.; Zackrisson, O.; Nilsson, M.-C. The charcoal effect in boreal forests: Mechanisms and consequences. Oecologia 1998, 115, 419-426. [CrossRef]

127. Aronsson, M. Skogsbetesmarker; Swedish Board of Agriculture: Jönköping, Sweden, 2013. (In Swedish)

128. Westin, A.; Lennartsson, T. Skogsbetesmarker i Sverige: Historia, Ekologi, Natur- och Kulturmiljövård; Centrum för Biologisk Mångfald: Uppsala, Sweden, 2018. (In Swedish)

129. Oldén, A.; Raatikainen, K.J.; Tervonen, K.; Halme, P. Grazing and soil pH are biodiversity drivers of vascular plants and bryophytes in boreal wood-pastures. Agricult. Ecosyst. Environ. 2016, 222, 171-184. [CrossRef]

130. Kardell, L. Om skogsbetet $i$ allmänhet och det $i$ klövsjö $i$ synnerhet; Department of Environmental Forestry, The Swedish University of Agricultural Sciences: Uppsala, Sweden, 2008. (In Swedish)

131. Austrheim, G.; Eriksson, O. Plant species diversity and grazing in the Scandinavian mountains-Patterns and processes at different spatial scales. Ecography 2001, 24, 683-695. [CrossRef]

132. Oinonen, E. Sporal regeneration of ground pine (Lycopodium complanatum L.) in southern Finland in the light of the size and age of its clones. Acta For. Fenn. 1967, 83, 1-85. (In Finnish with English Summary)

133. Risberg, L.; Granström, A. Exploiting a window in time. Fate of recruiting populations of two rare fire-dependent Geranium species after forest fire. Plant Ecol. 2014, 215, 613-624. [CrossRef]

134. Ersgård, L. Medieval and early modern towns in Sweden in a long-term perspective. In Urban Variation-Utopia, Planning and Practice; Cornell, P., Ersgård, L., Nilsen, A., Eds.; Department of Historical Studies, University of Gothenburg: Gothenburg, Sweden; pp. 73-95.

135. Sjöbeck, M. Lövängskulturen i Sydsverige. Dess uppgång, utveckling och tillbakagång. Ymer 1933, 53, 33-66. (In Swedish)

136. Andersson, R.; Östlund, L.; Lundqvist, R. Carved trees in grazed forests in boreal Sweden: Analysis of remaining tress, interpretation of past land-use and implications for conservation. Veg. Hist. Archaeobot. 2005, 14, 149-158. [CrossRef]

137. Svensson, E. The Scandinavian shieling-Between innovation and tradition. In Historical Archaeologies of Transhumance across Europe; Costello, E., Svensson, E., Eds.; Routledge: London, UK, 2018; pp. 15-27.

138. Fuller, D.Q.; Allaby, R.G.; Stevens, C. Domestication as innovation: The entanglement of techniques, technology and chance in the domestication of cereal crops. World Archaeol. 2010, 42, 13-28. [CrossRef]

139. Eide, W.; Ahrné, K.; Bjelke, U.; Nordström, S.; Ottosson, E.; Sandström, J.; Sundberg, S. Tillstånd och trender för arter och deras livsmiljöer—Rödlistade arter i sverige 2020; SLU Artdatabanken: Uppsala, Sweden, 2020. (In Swedish with English Summary)

140. Swedish Board of Agriculture. Ängs-och betesmarksinventeringen. Available online: https://www2.jordbruksverket.se/ webdav/files/SJV/trycksaker/Pdf_rapporter/ra05_1.pdf (accessed on 13 November 2020).

141. Larsson, C.; Boke Olén, N.; Brady, M. Naturbetesmarkernas Framtid: En fråga om lönsamhet; AgriFood Economics Centre: Lund, Sweden, 2020. (In Swedish)

142. Eriksson, O. Historical and current niche construction in an anthropogenic biome: Old cultural landscapes in southern Scandinavia. Land 2016, 5, 42. [CrossRef]

143. Raatikainen, K.J.; Barron, E.S. Current agri-environmental policies dismiss varied perceptions and discourses on management of traditional rural biotopes. Land Use Policy 2017, 69, 564-576. [CrossRef] 